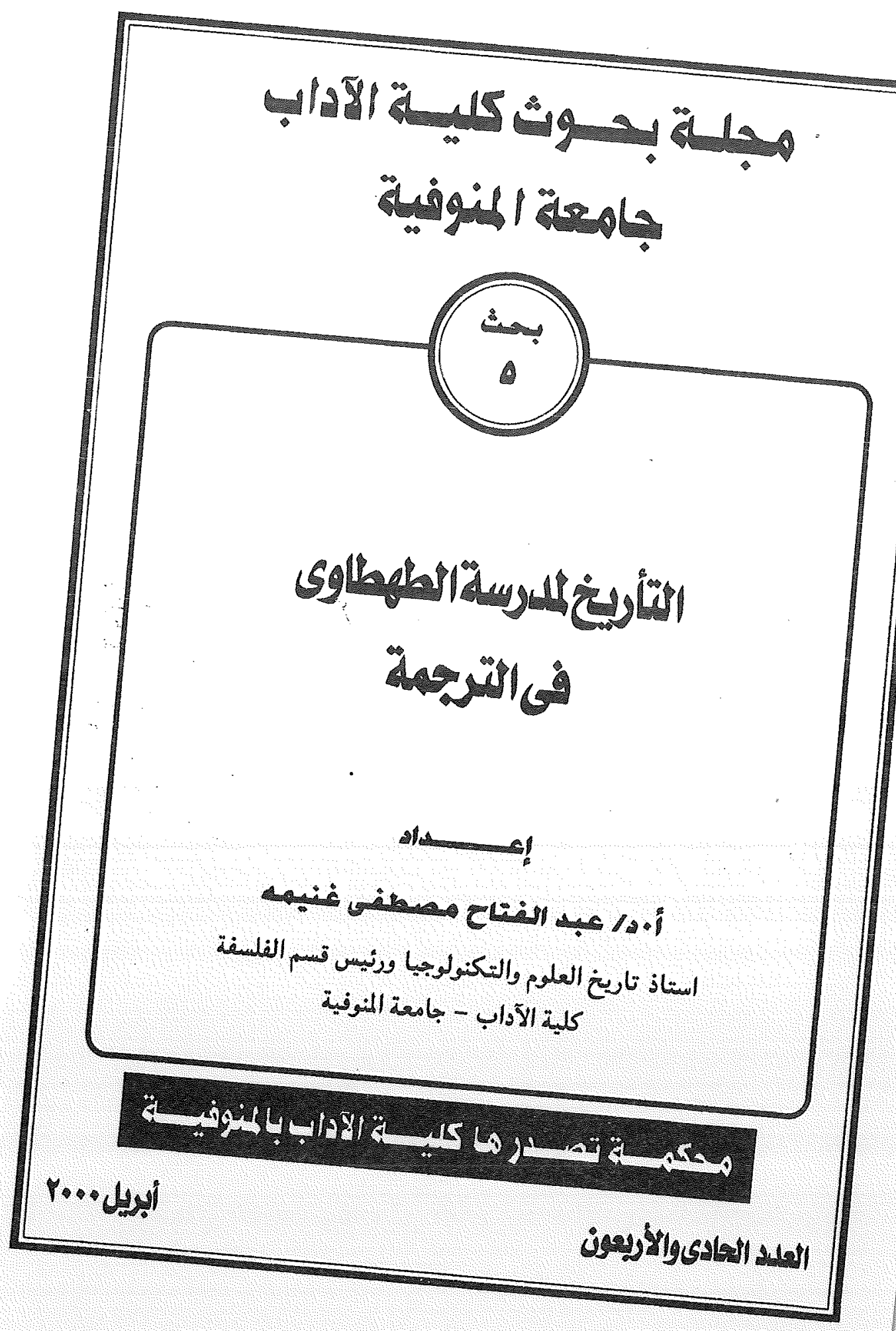


التأريخ لمدرسية الطوهاوى فيى الترجمية

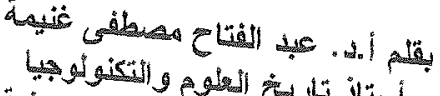

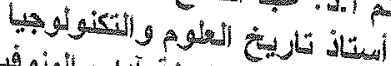

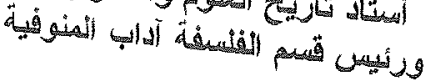

فُهِر الترجهة :

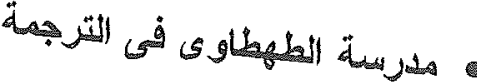

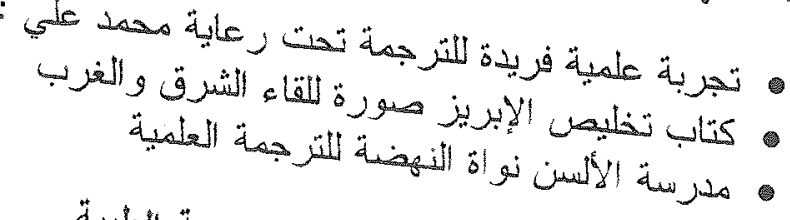

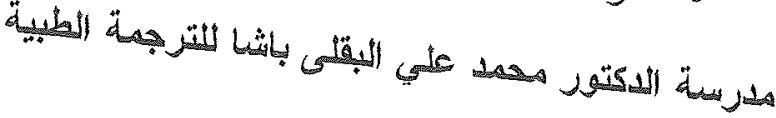

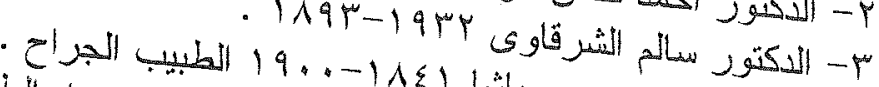

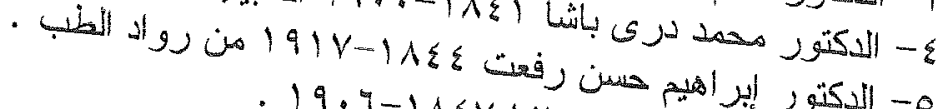

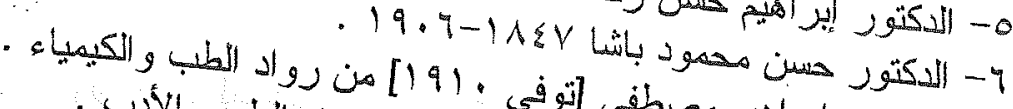

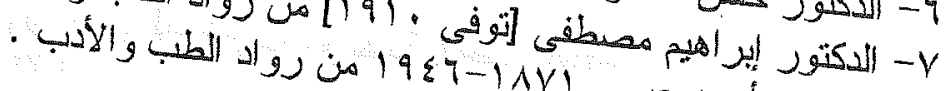

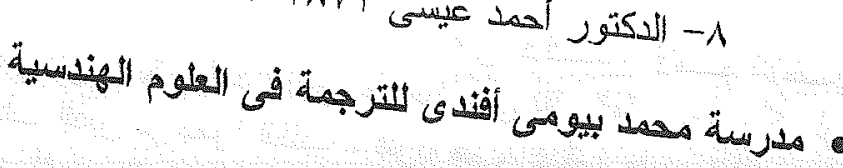

-

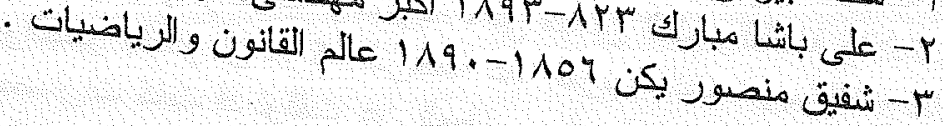

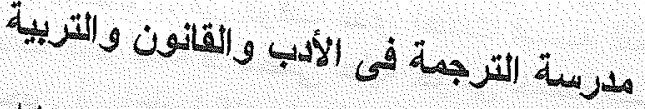

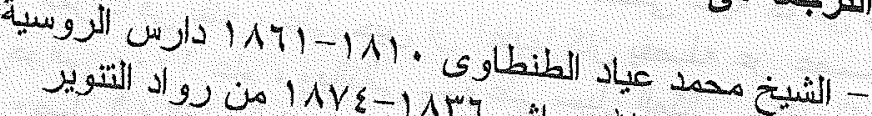

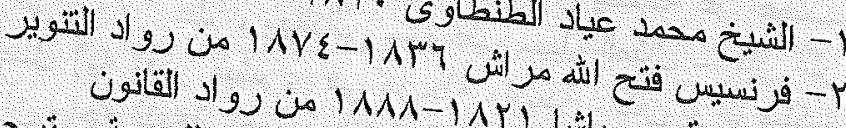

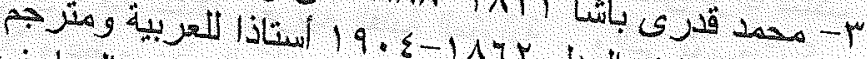

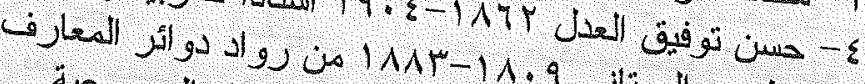

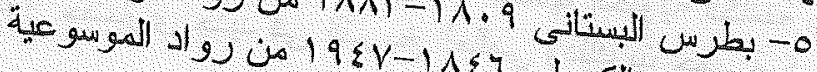
4- انستاسن الكرن الى 


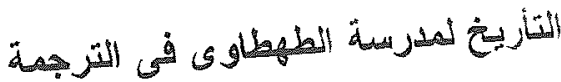

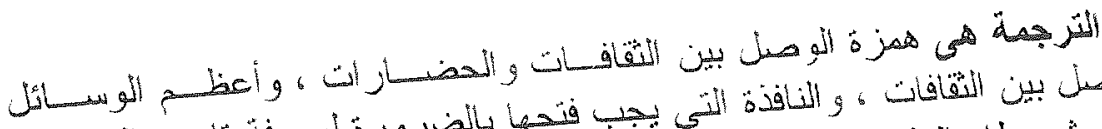

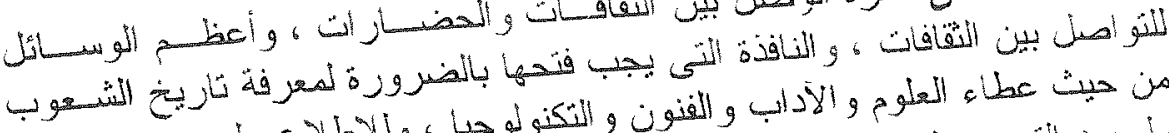

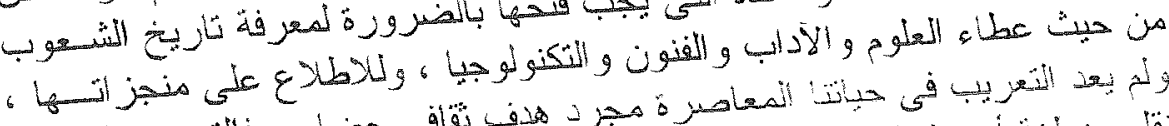

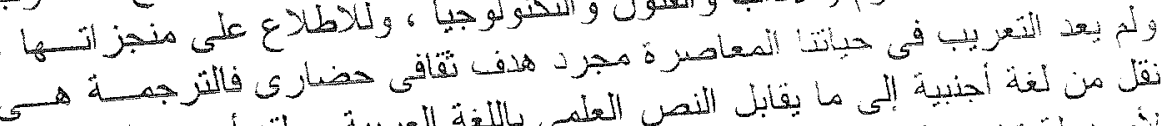

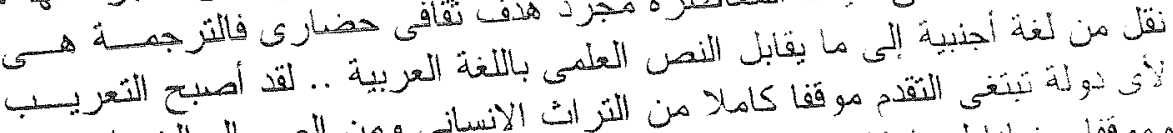

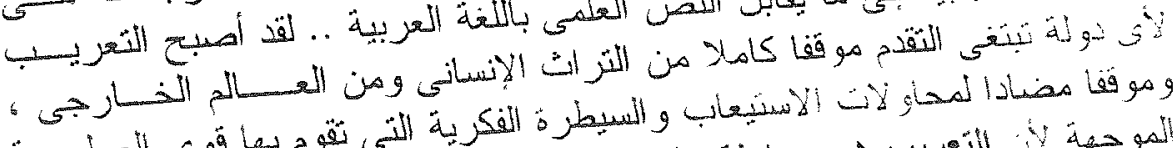

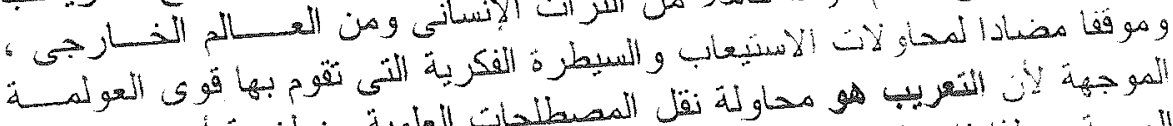

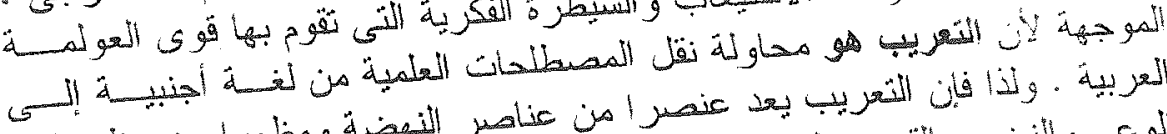

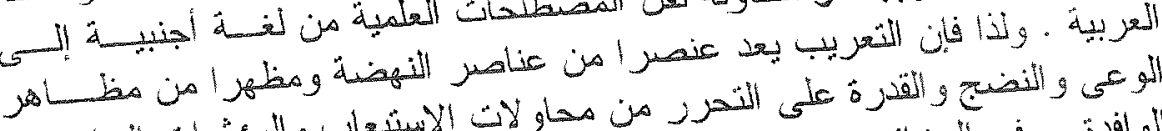

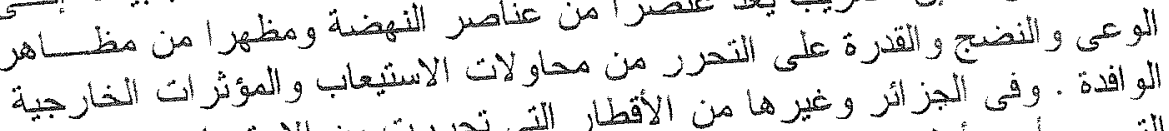

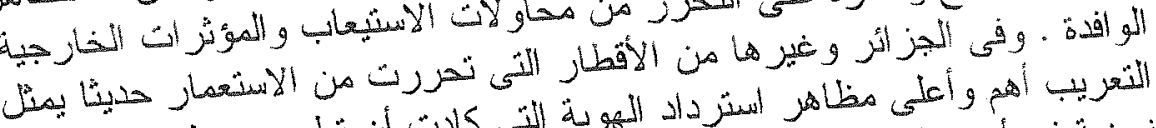

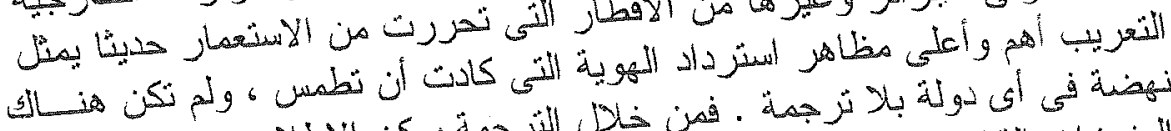

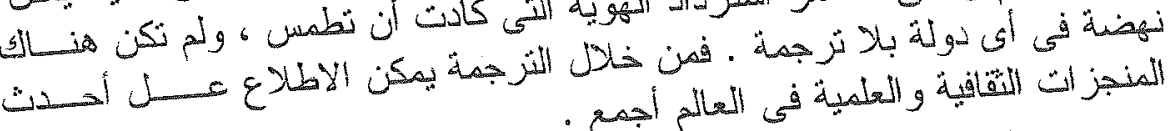

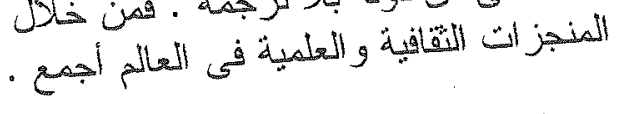

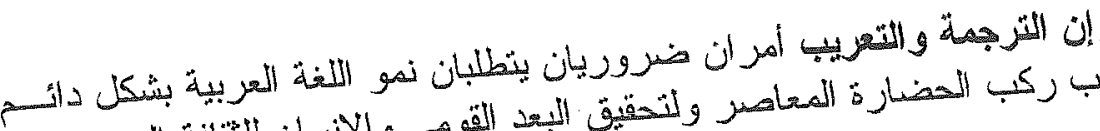

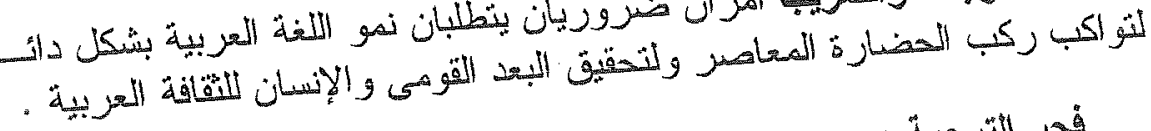

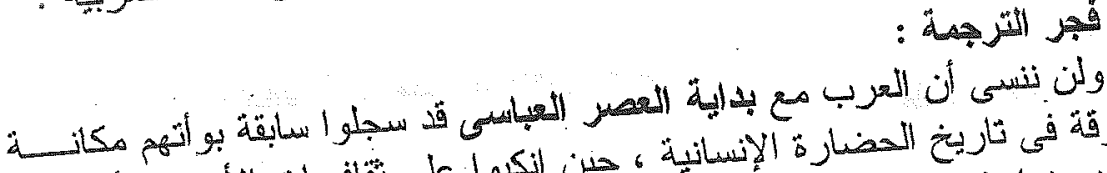

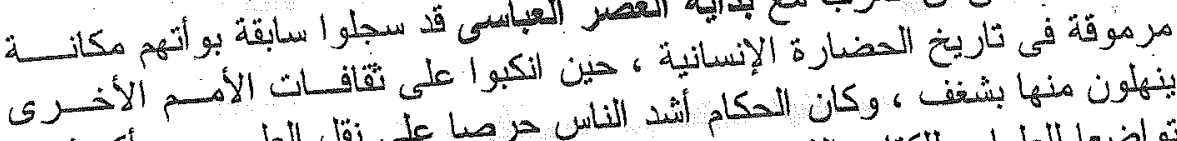

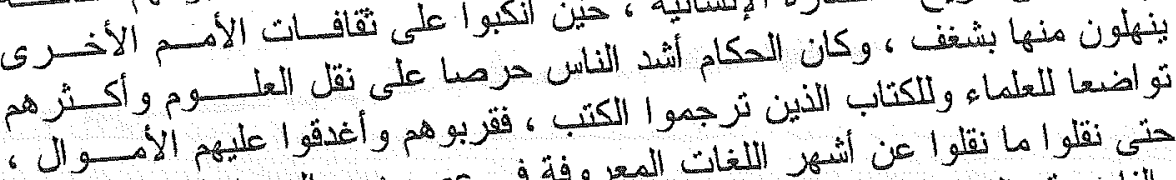

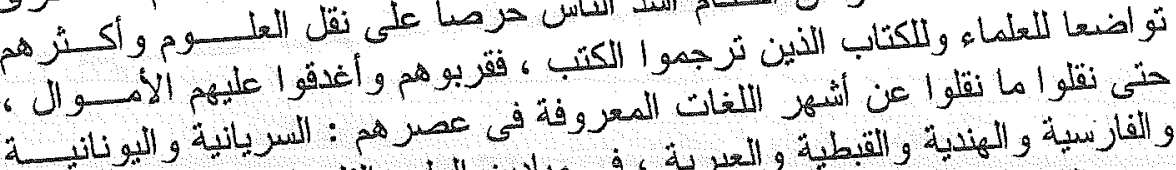

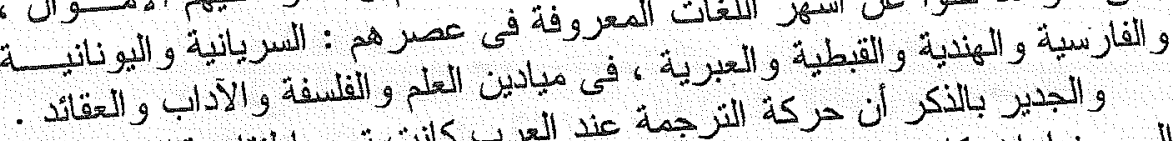

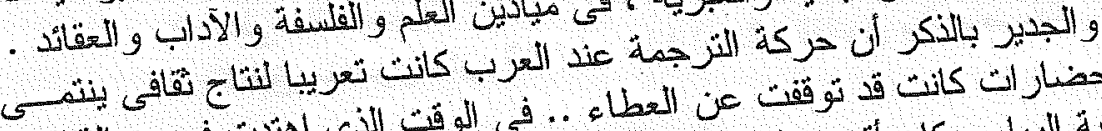

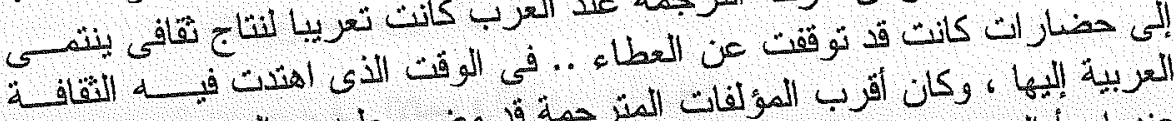

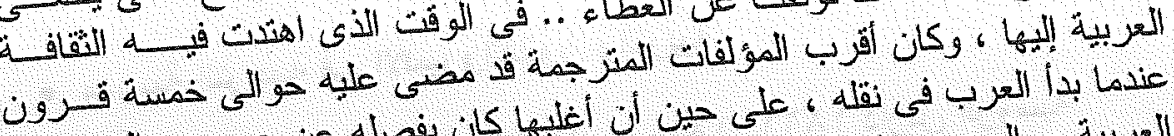

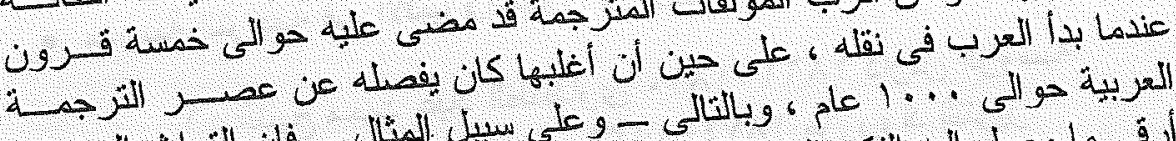

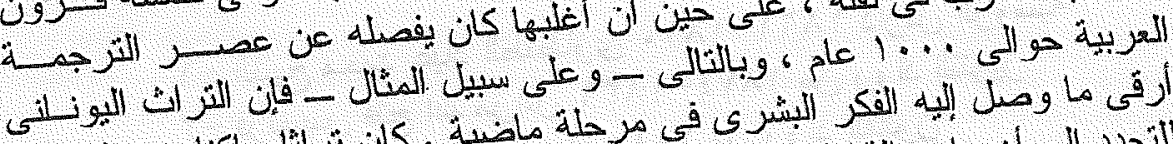

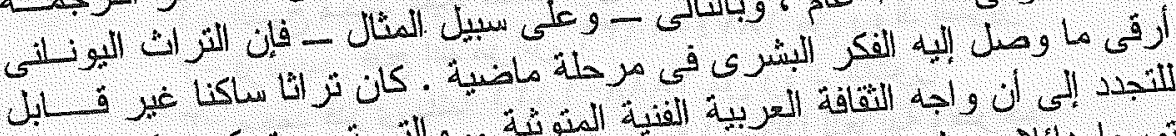

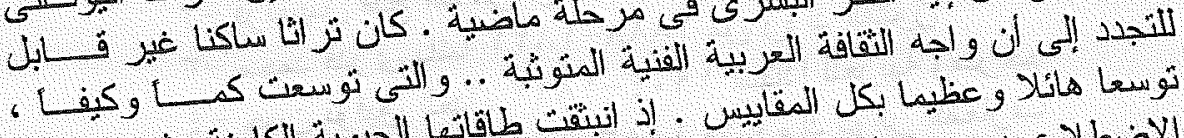

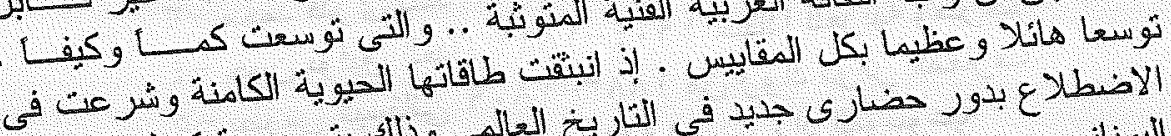

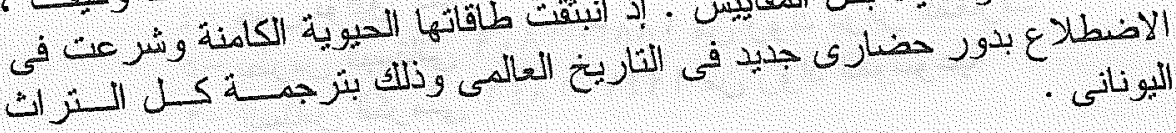




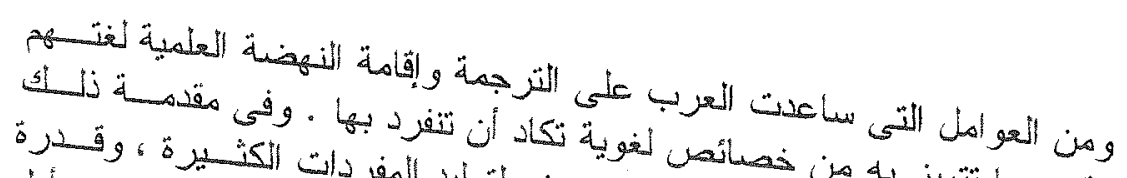

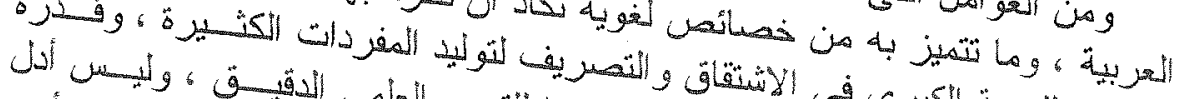

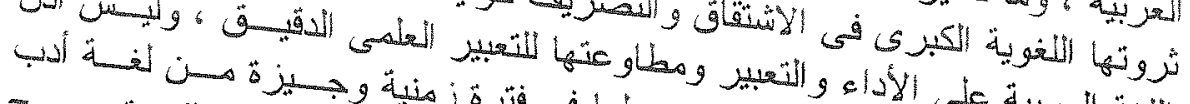

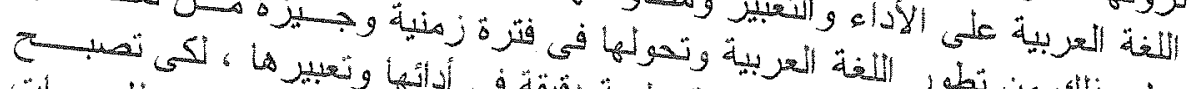

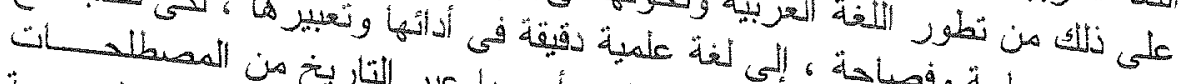

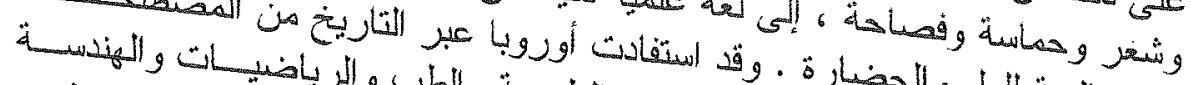

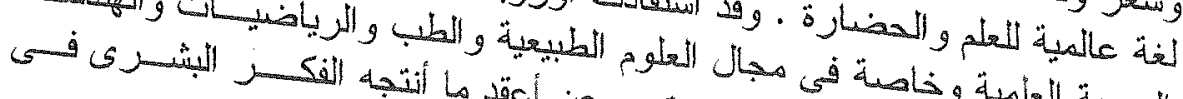

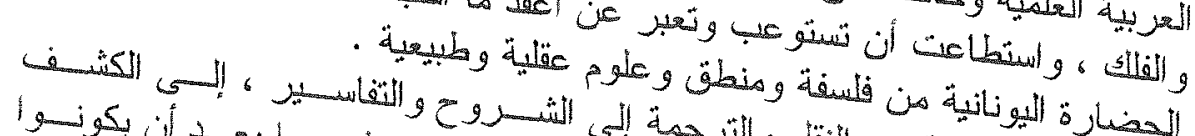

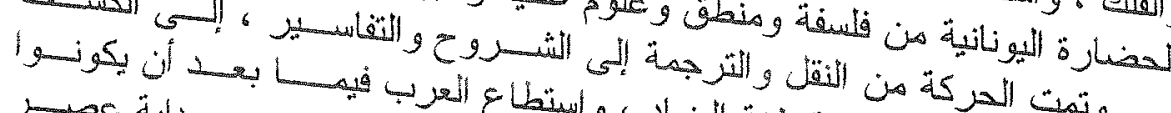

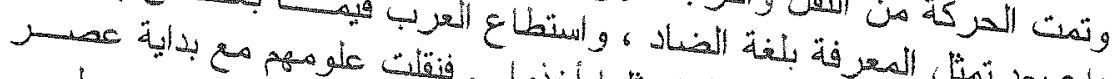

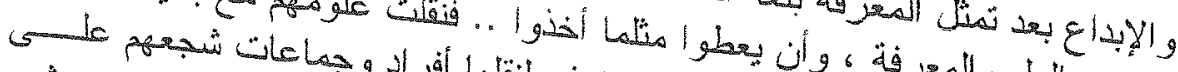

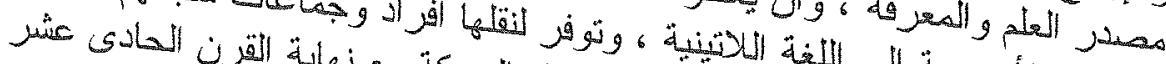

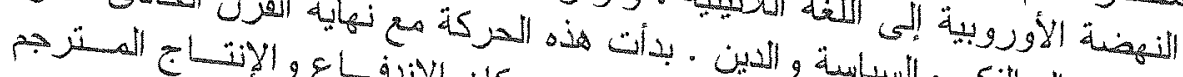

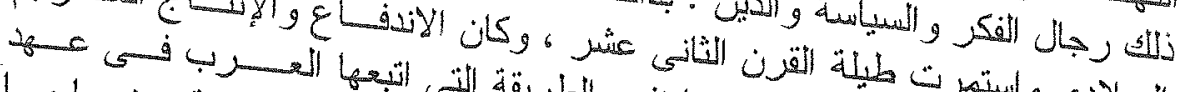

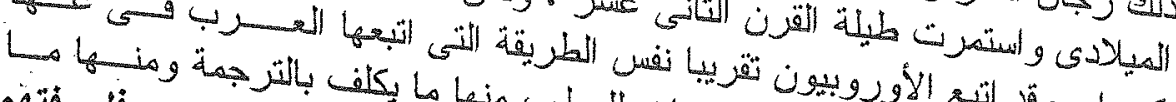

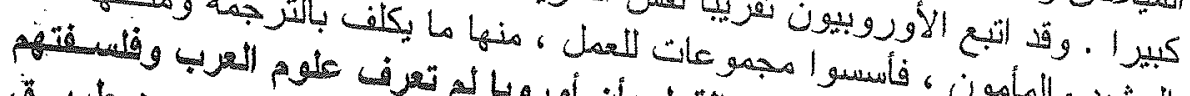

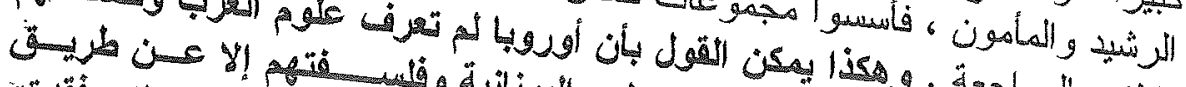

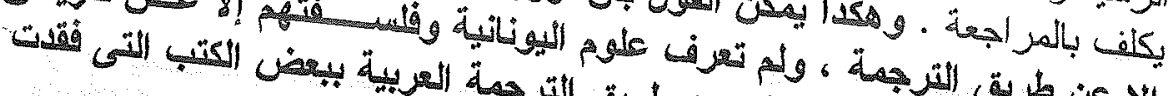

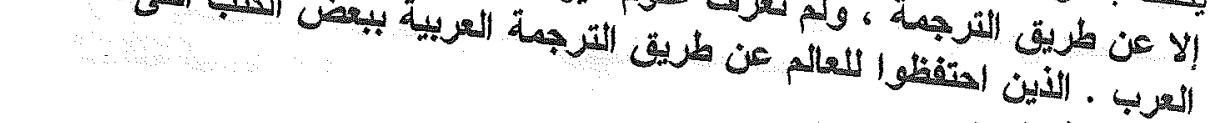

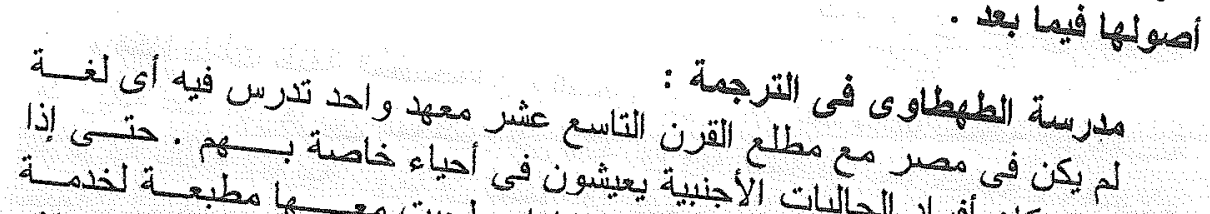

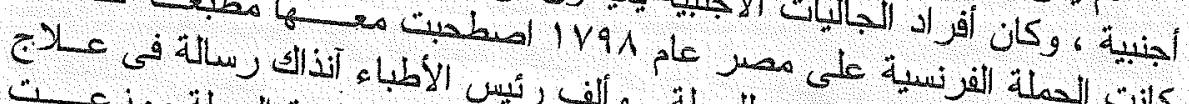

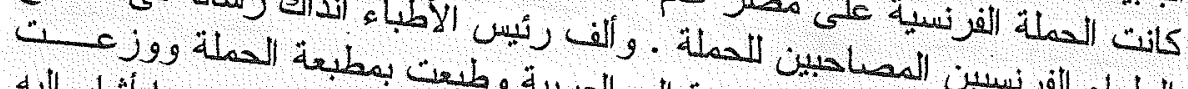

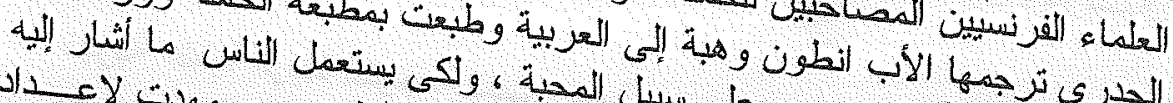

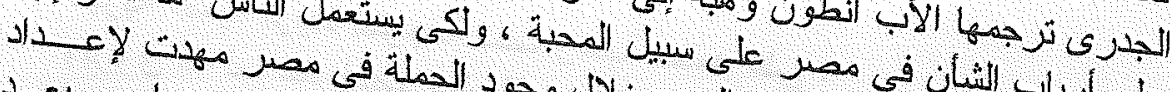

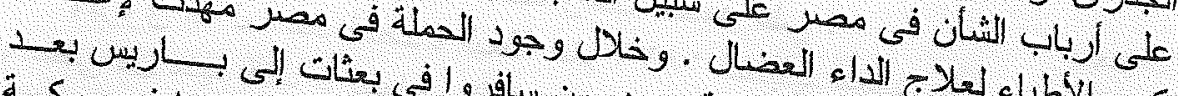

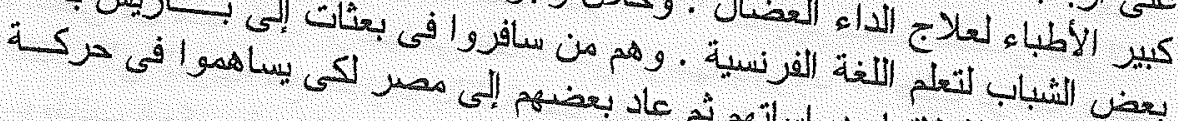

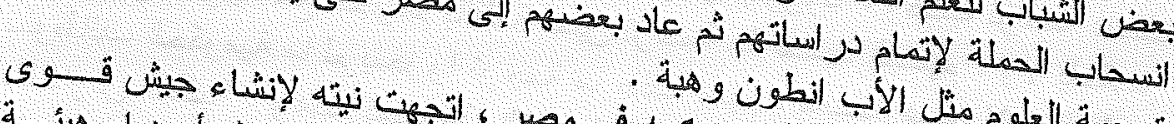

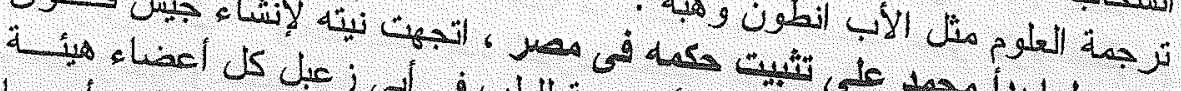

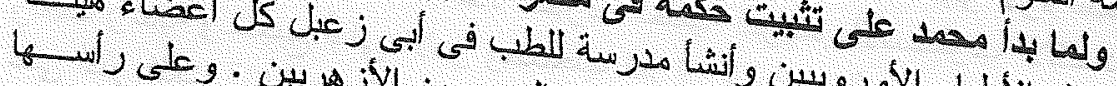
10r

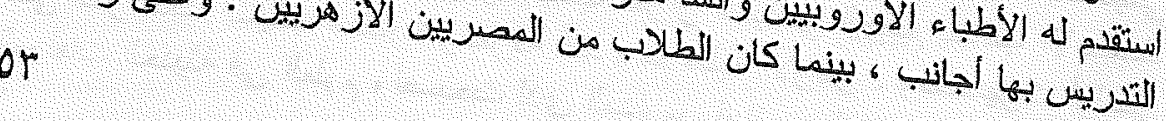




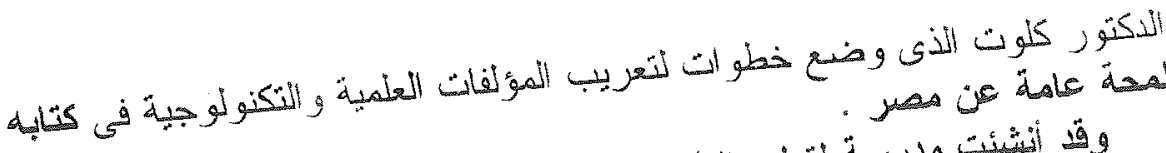

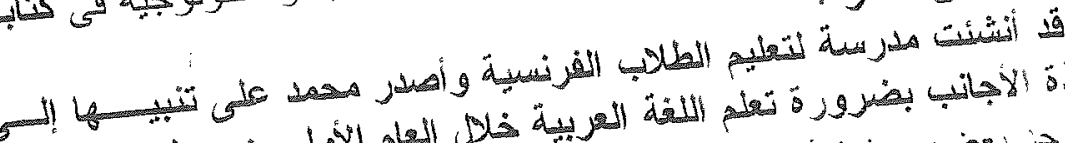

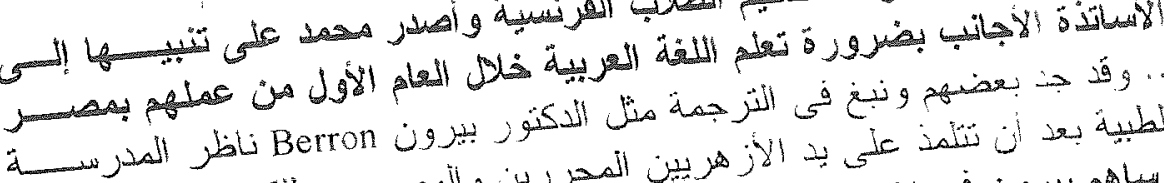

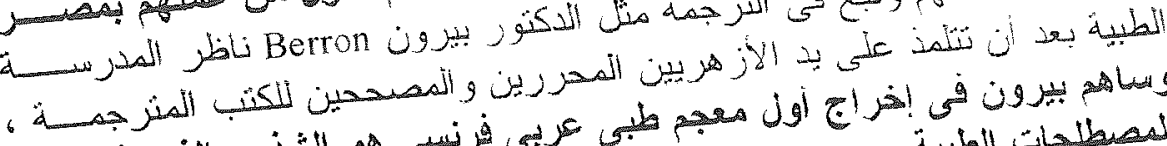

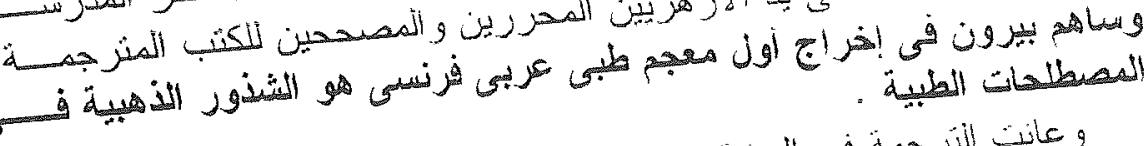

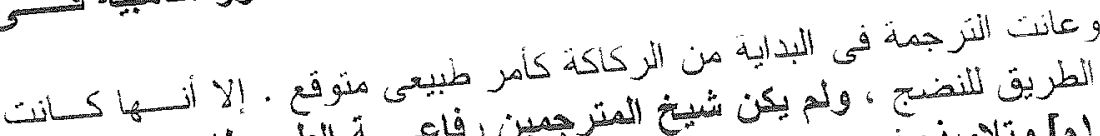

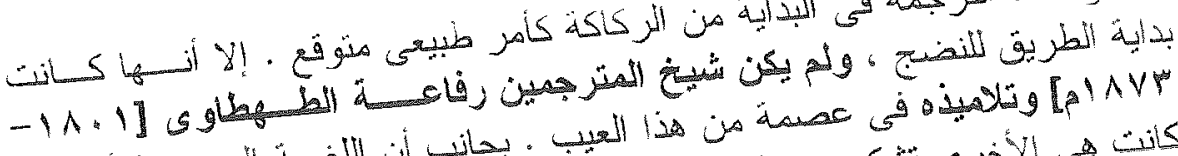

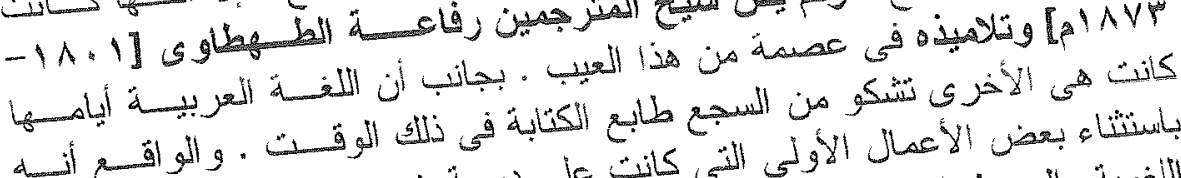

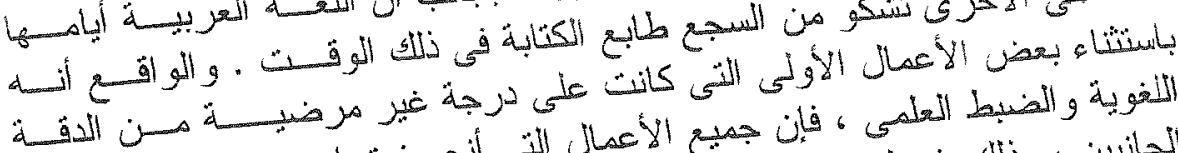

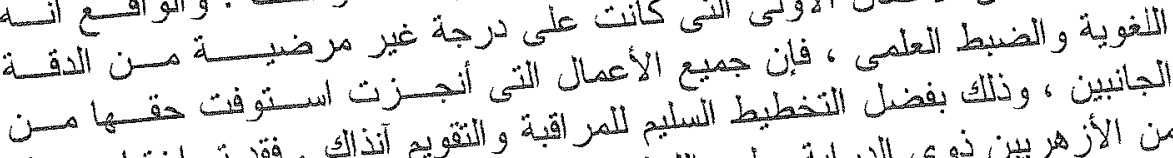

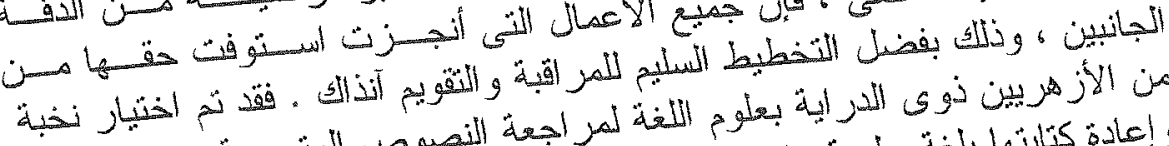

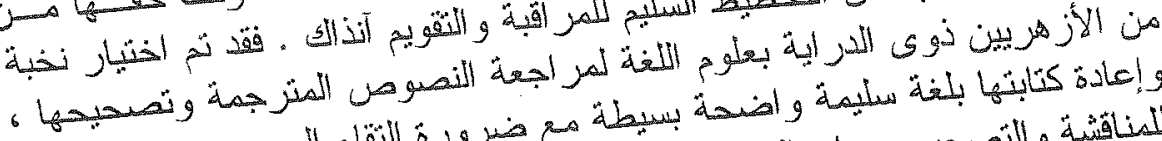

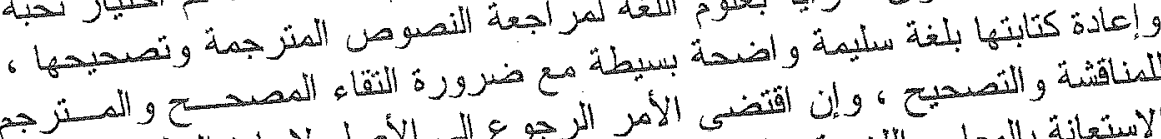

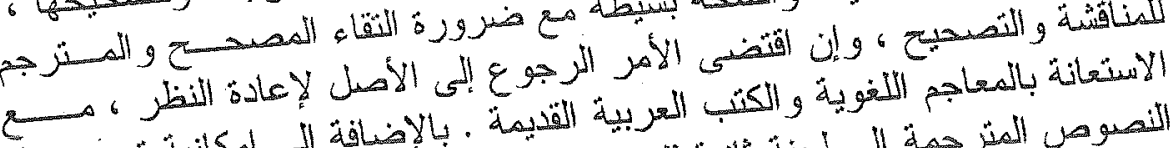

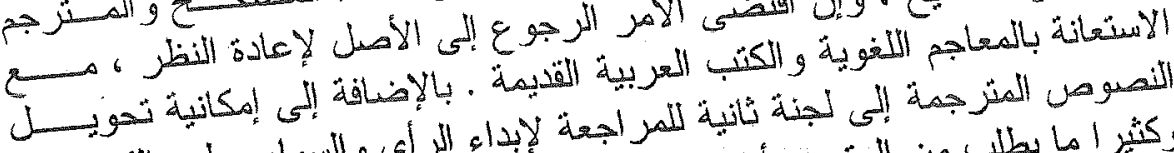

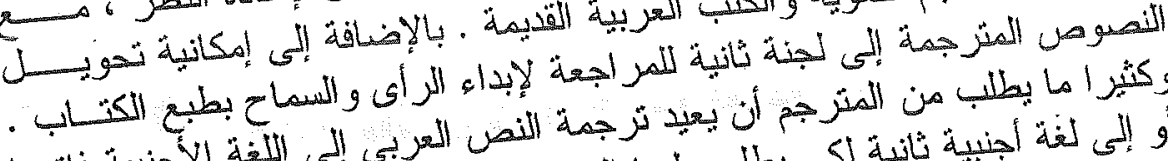

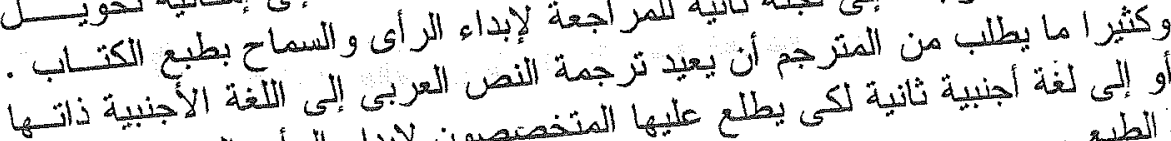

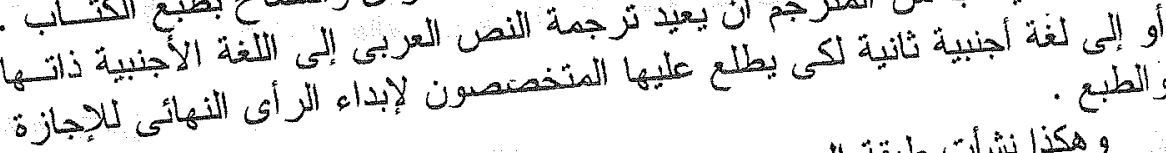

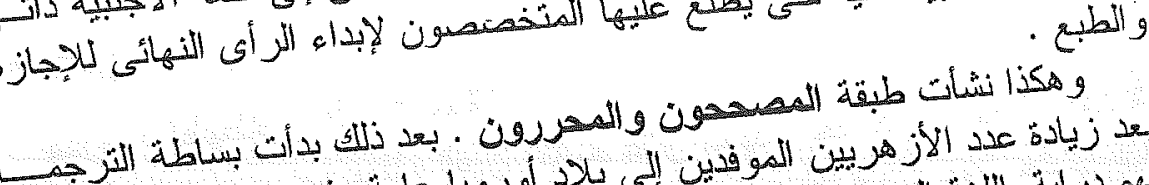

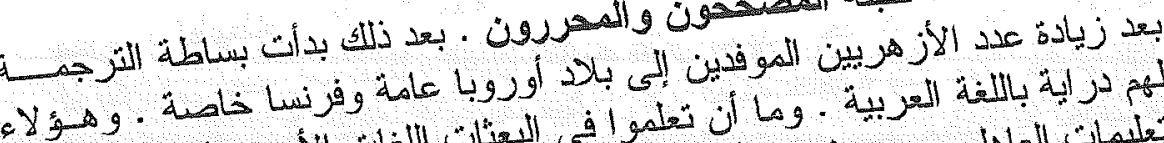

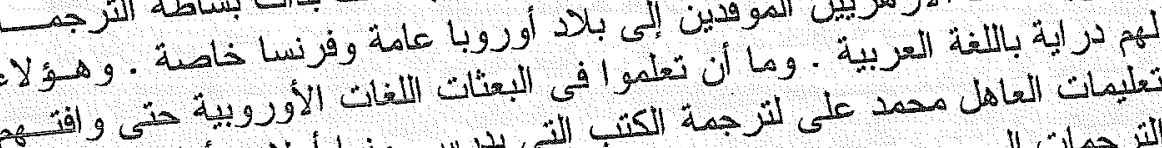

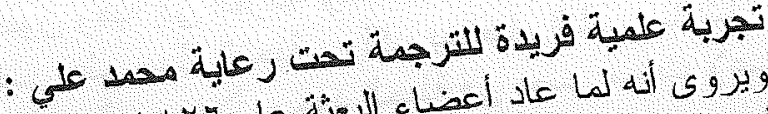

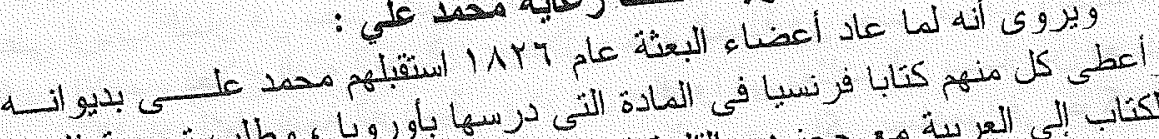

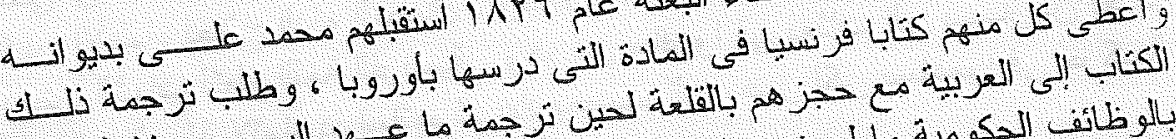

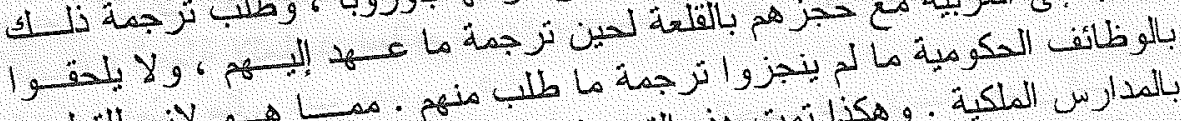

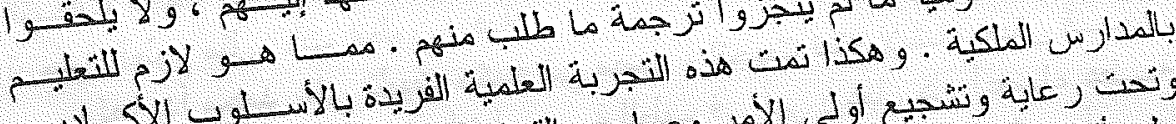

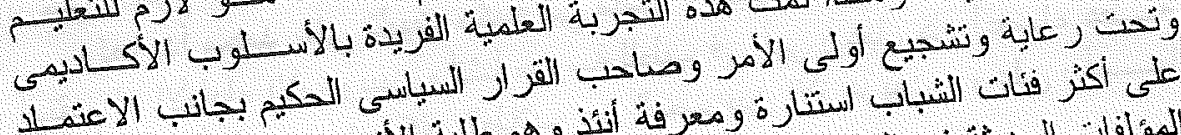

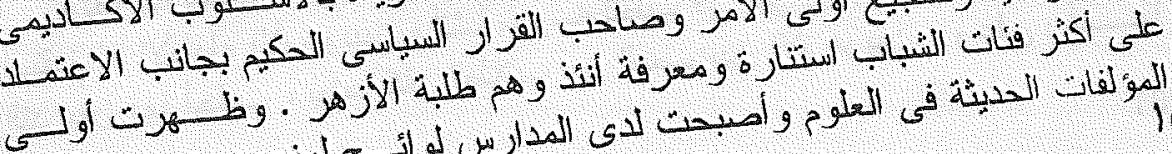
ج

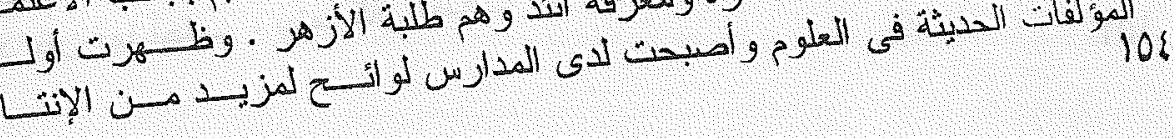




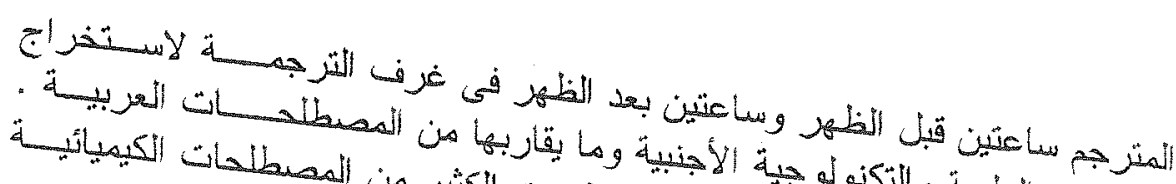

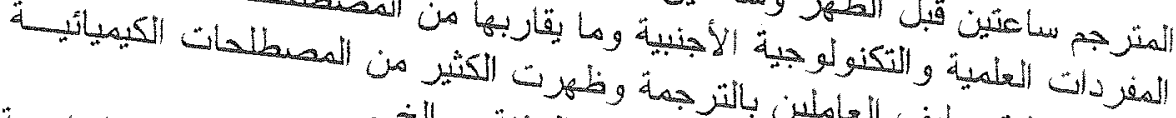

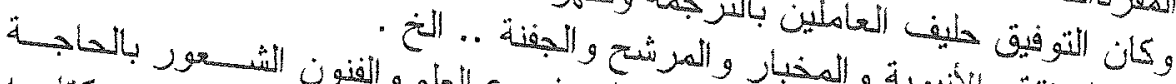

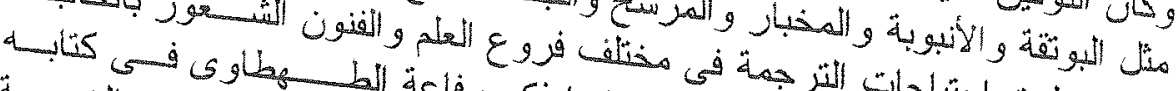

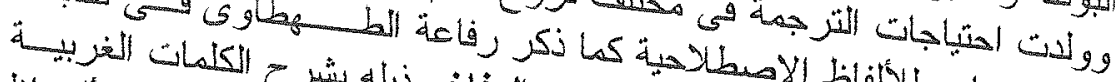

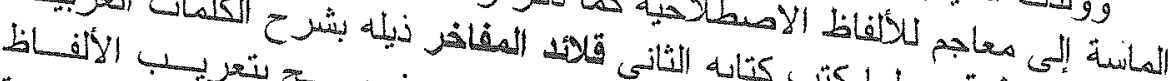

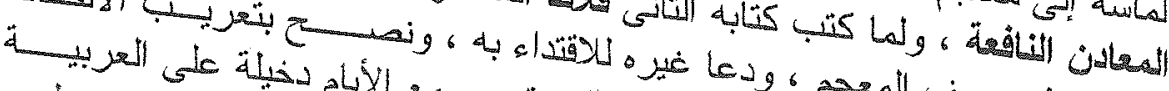

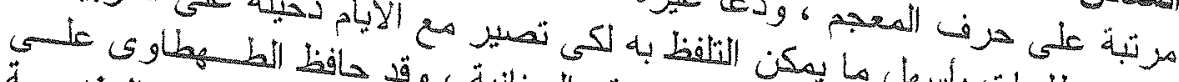

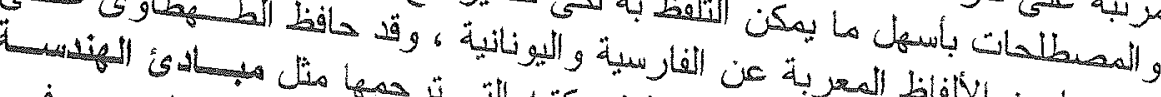

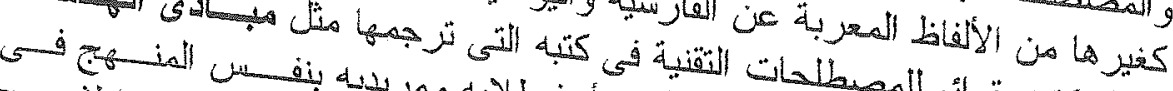

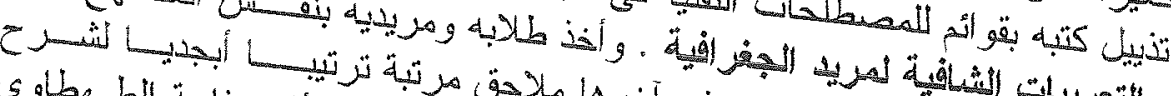

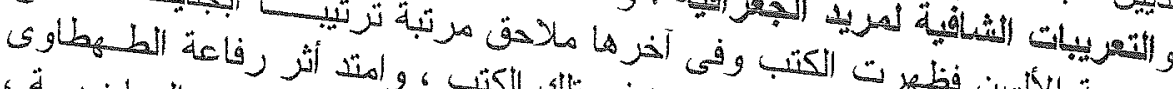

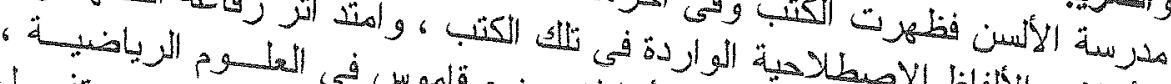

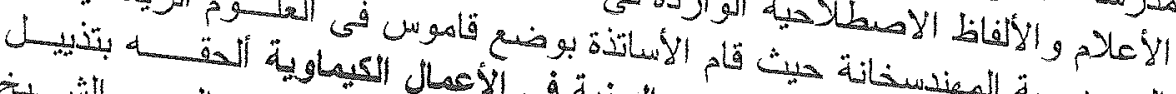

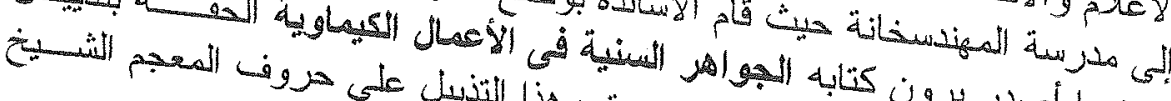

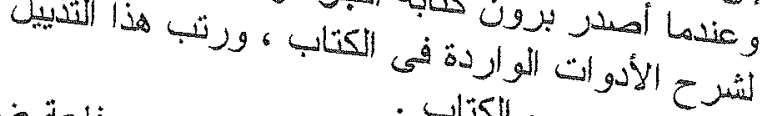

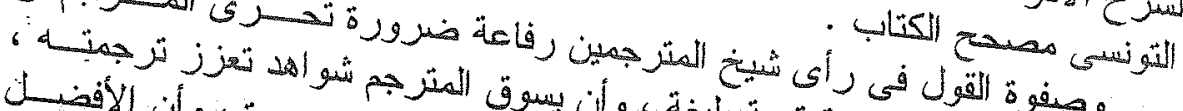

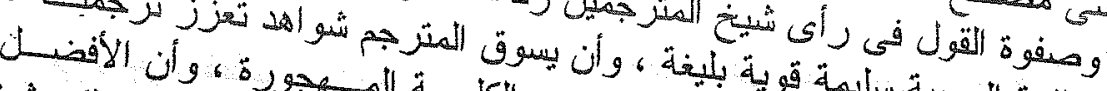

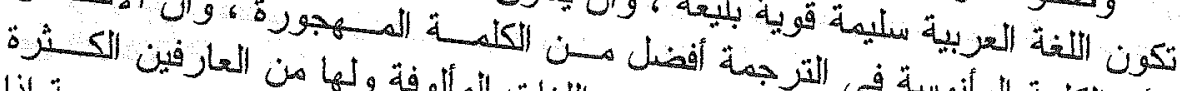

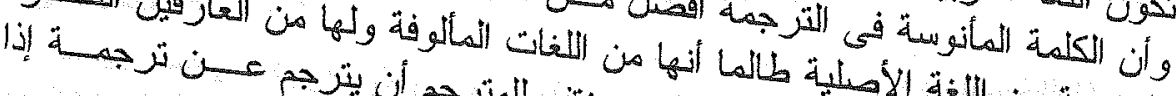

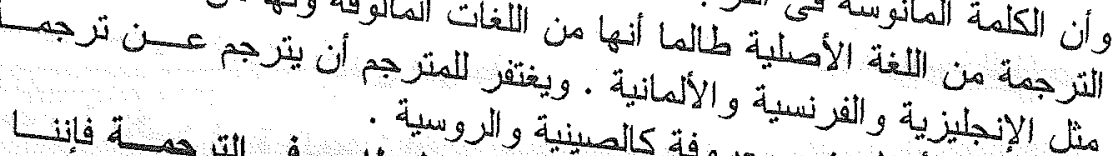

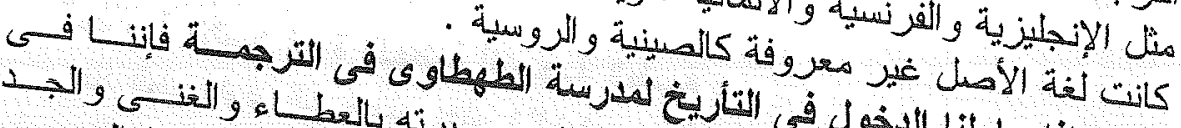

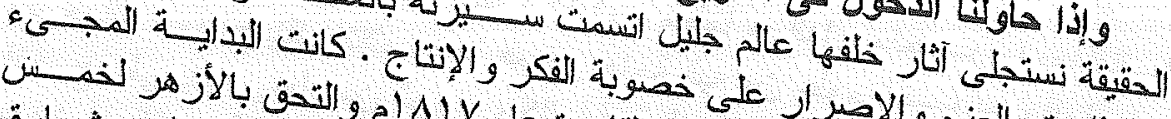

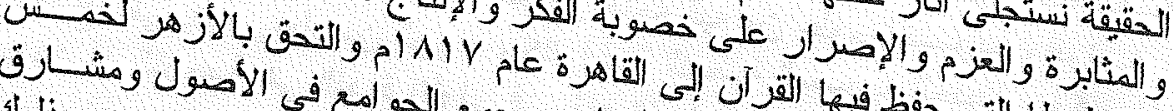

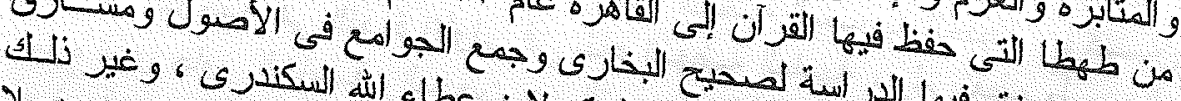

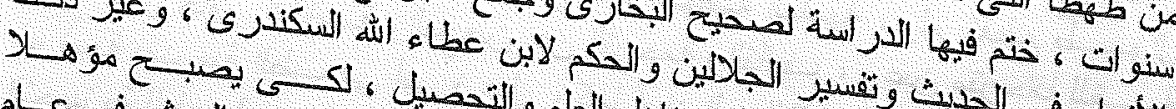

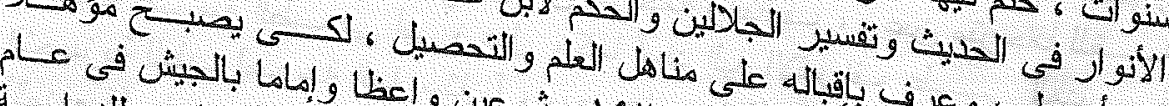

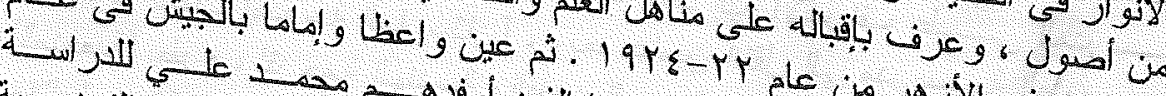

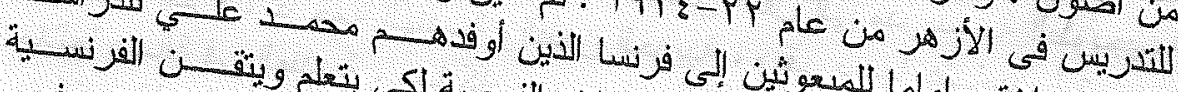

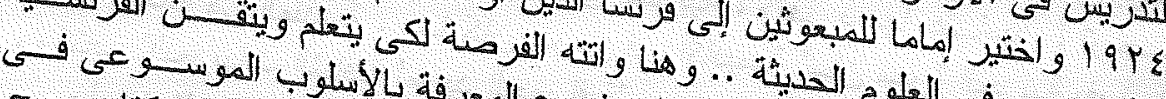

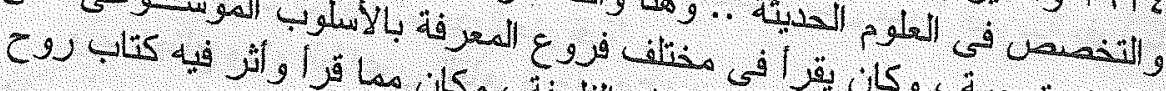

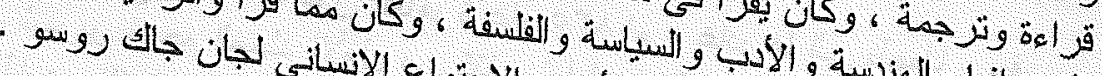




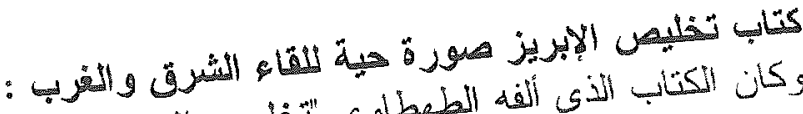

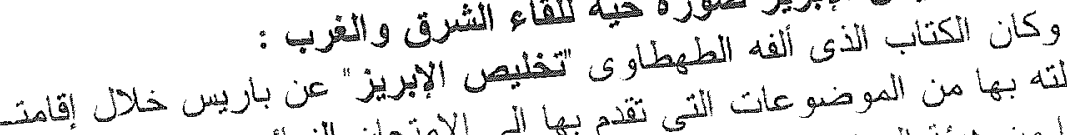

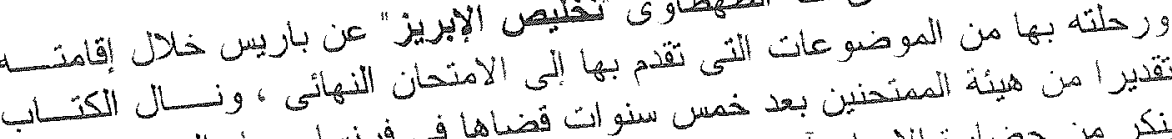

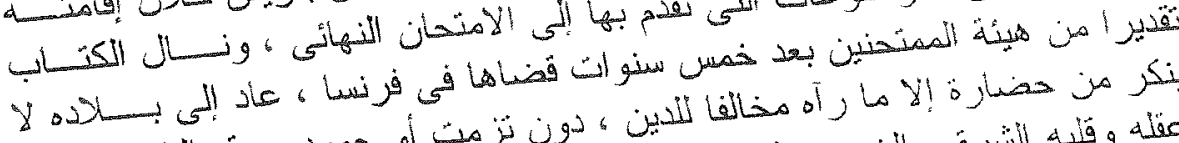

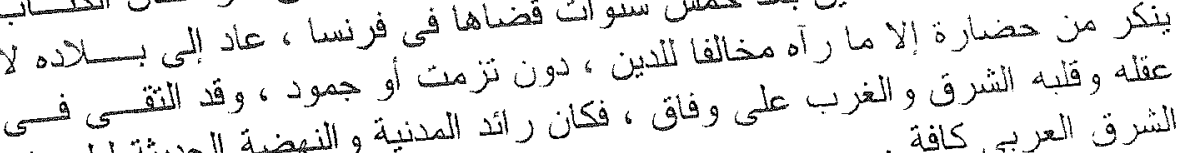

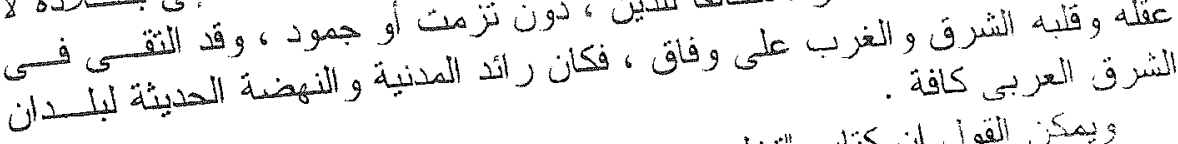

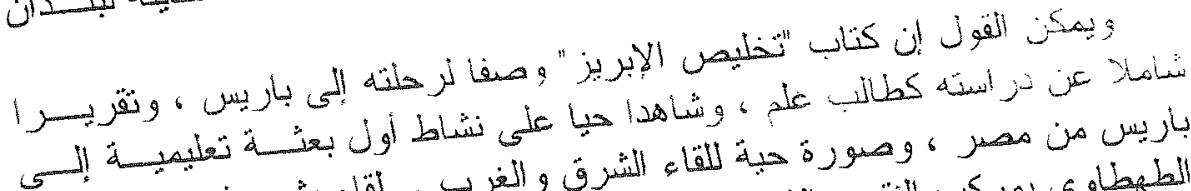

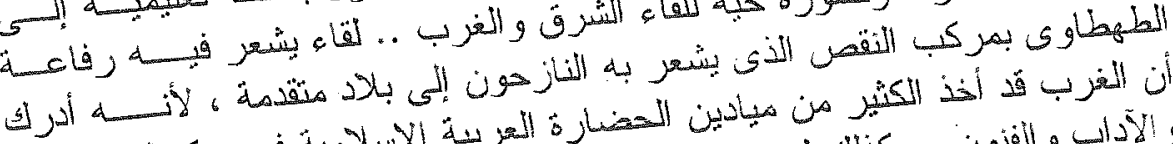

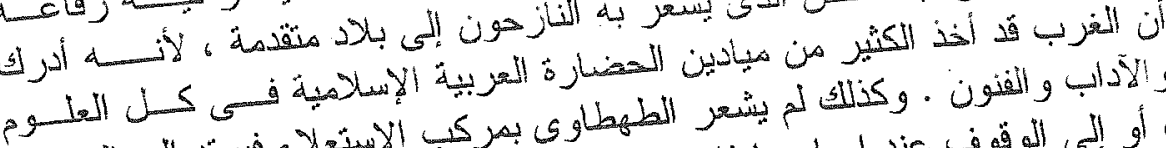

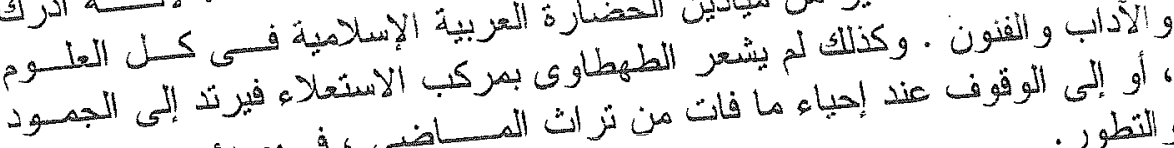

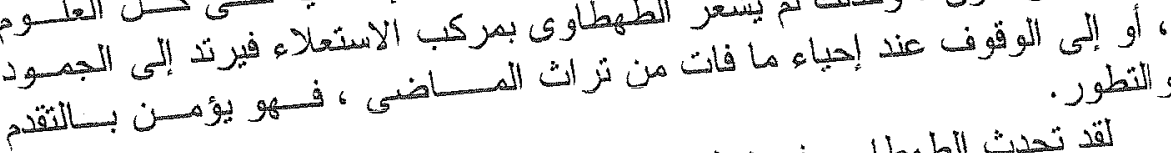

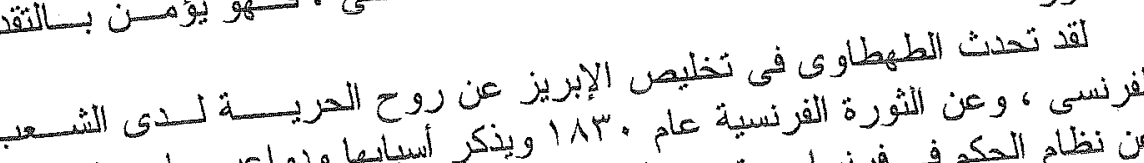

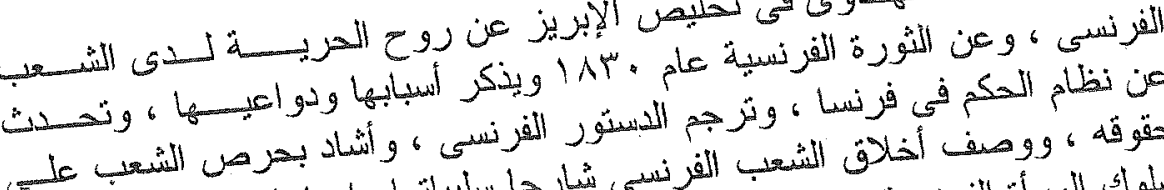

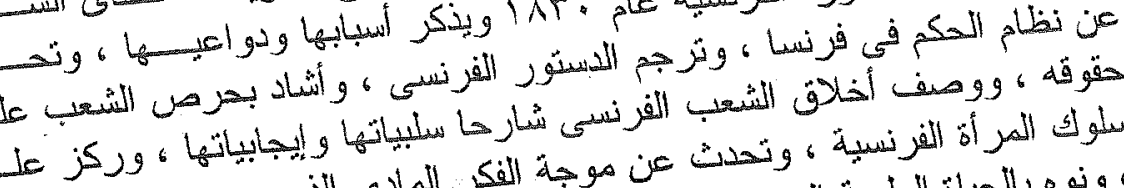

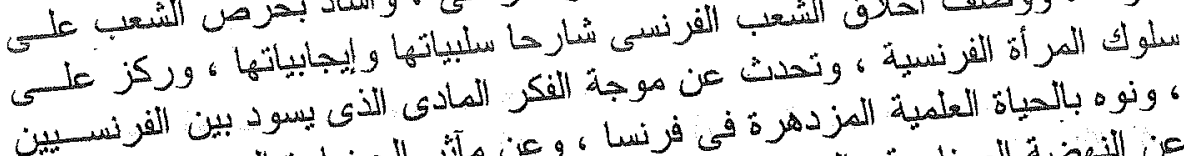

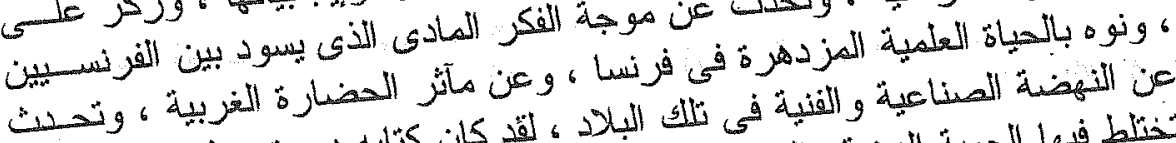

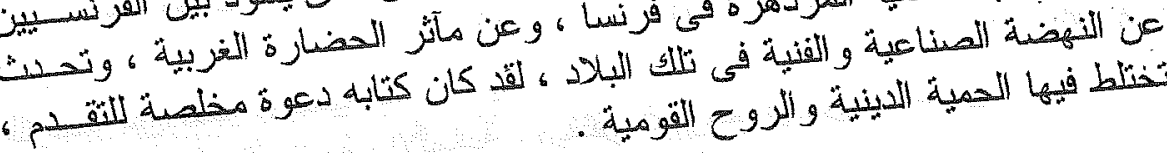

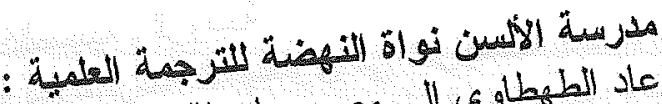

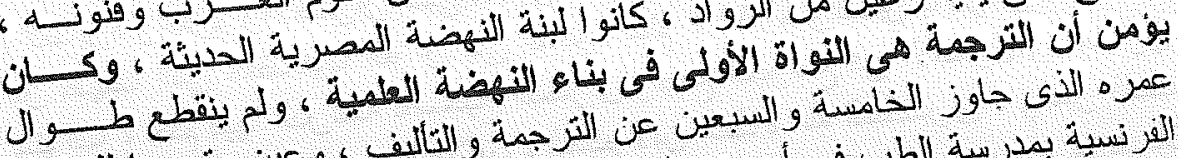

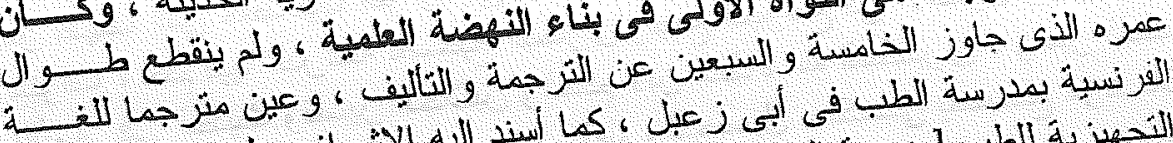

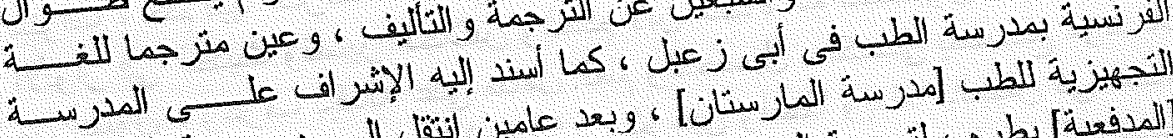

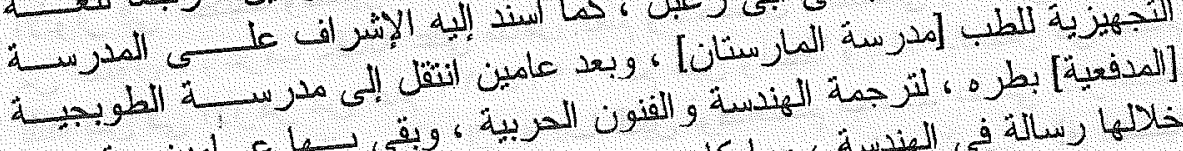

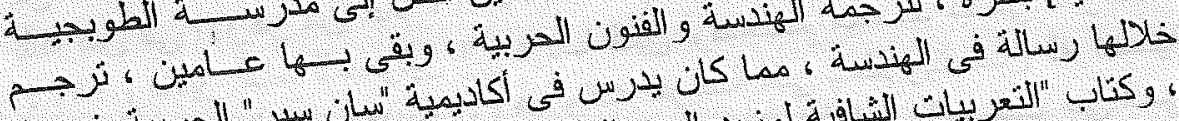

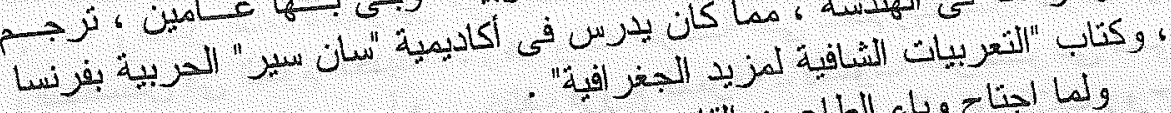

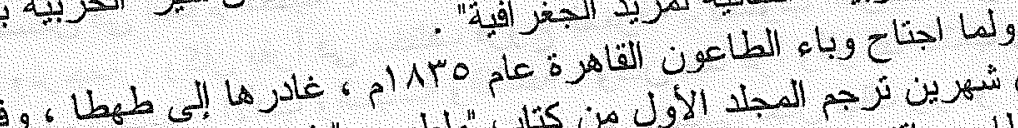

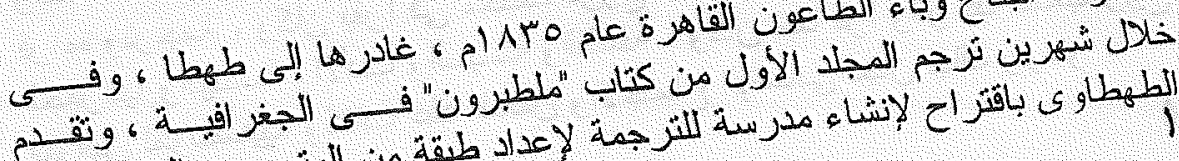

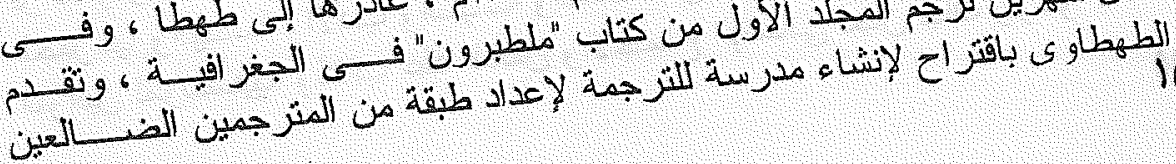




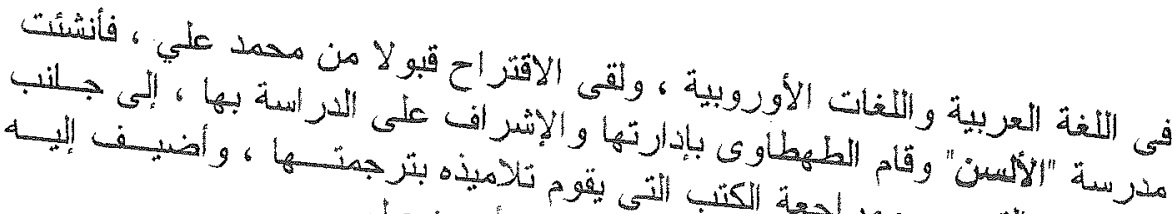

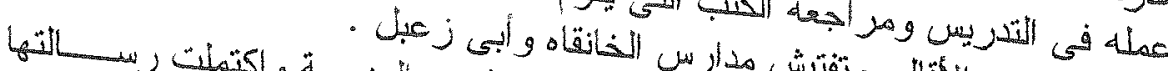

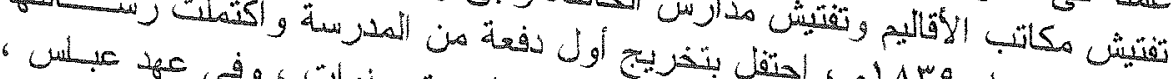

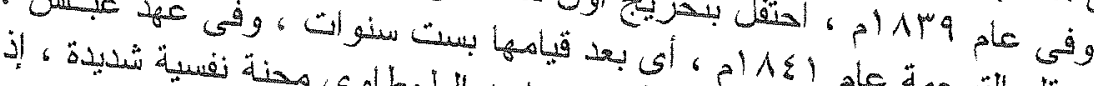

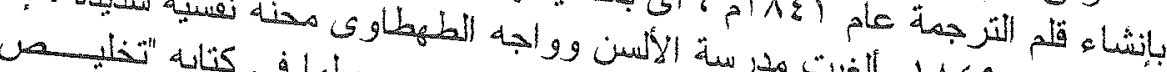

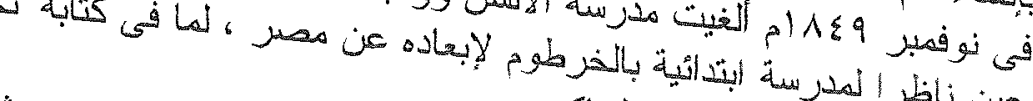

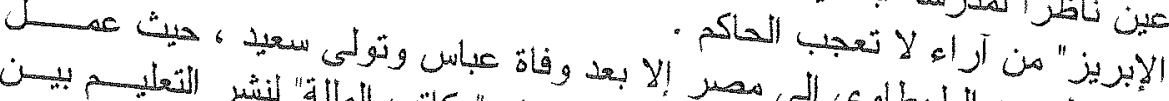

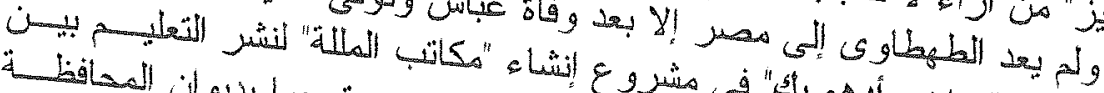

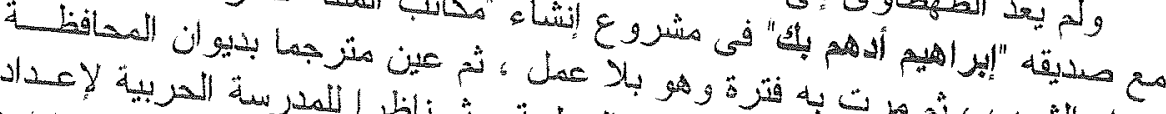

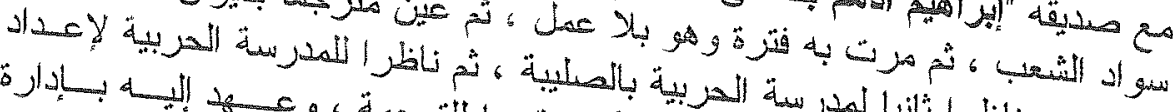

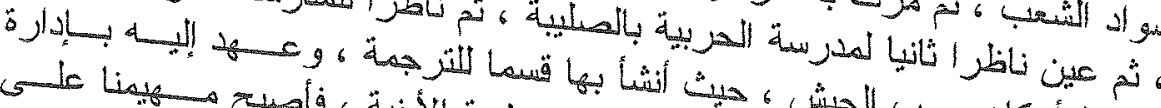

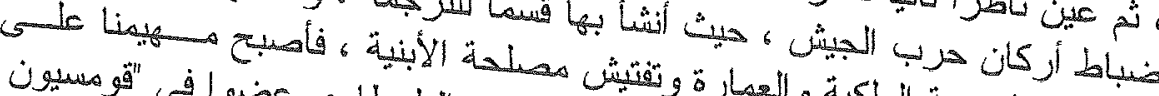

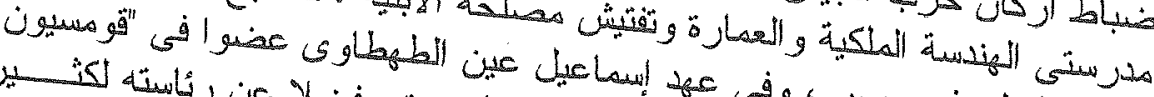

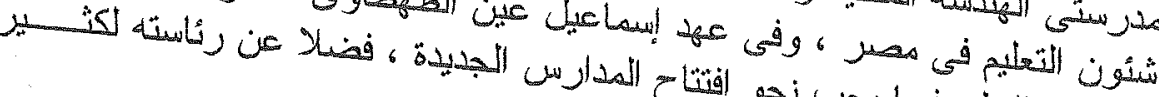

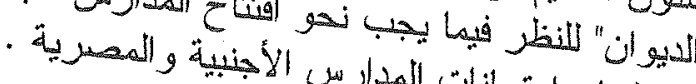

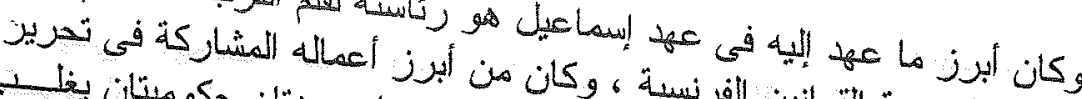

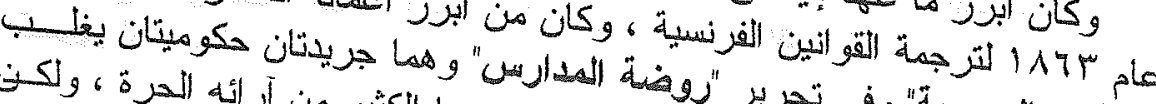

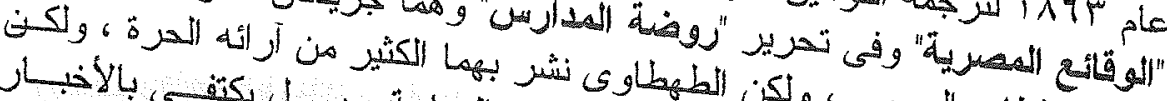

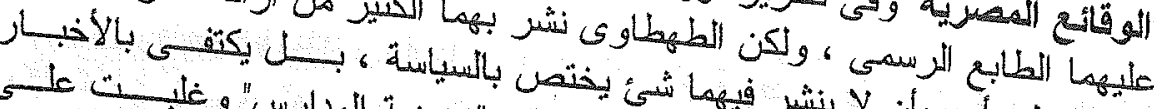

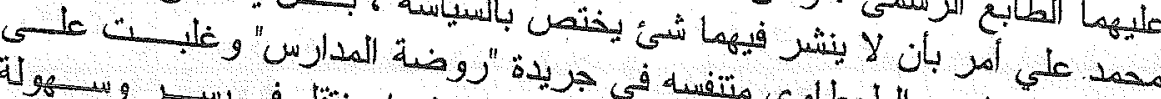

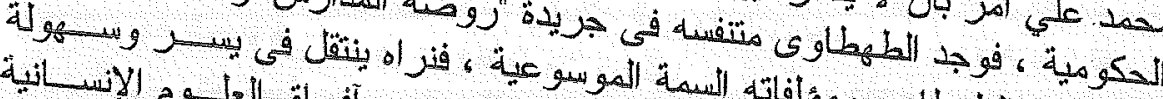

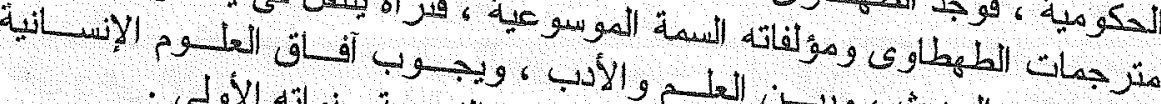

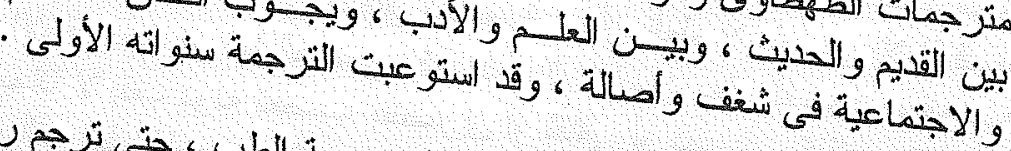

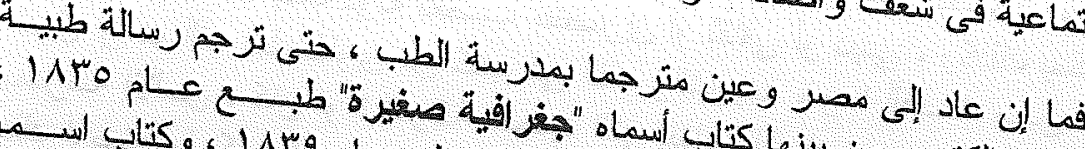

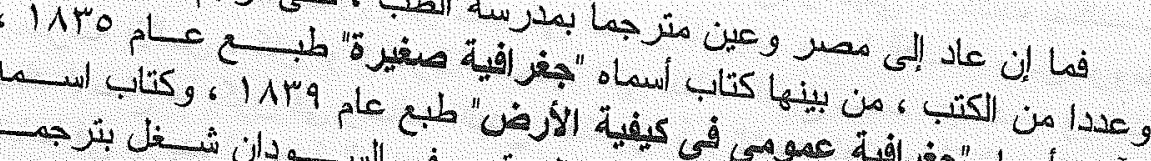

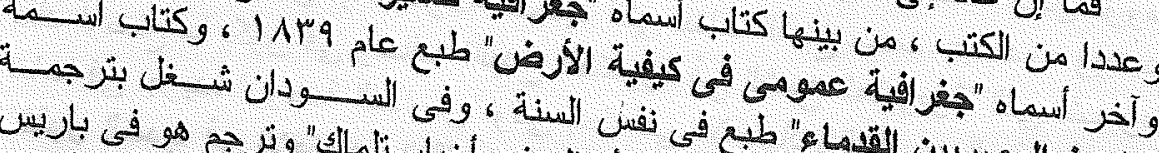

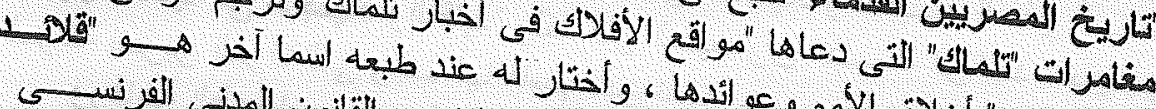

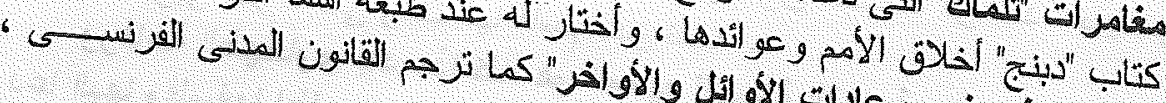

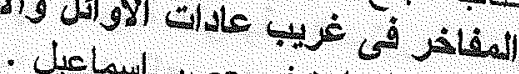




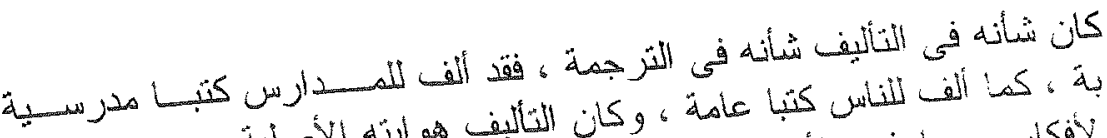

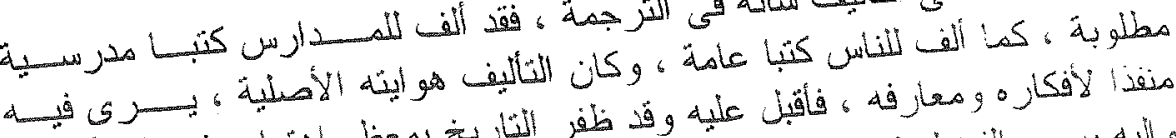

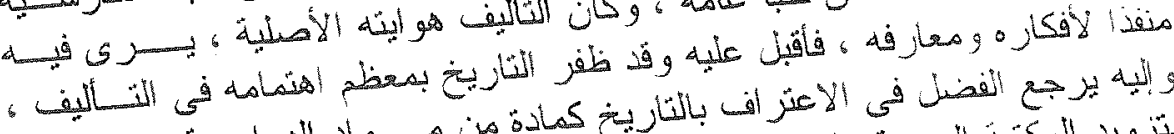

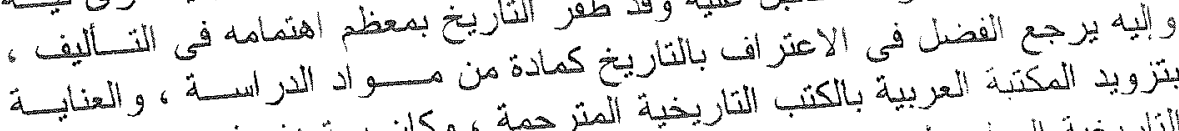

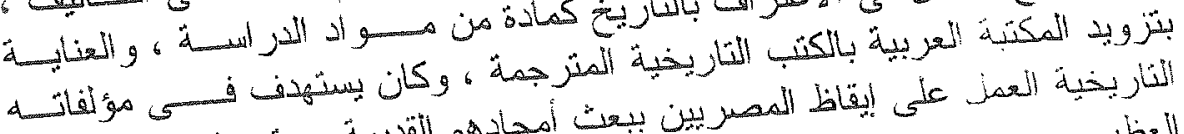

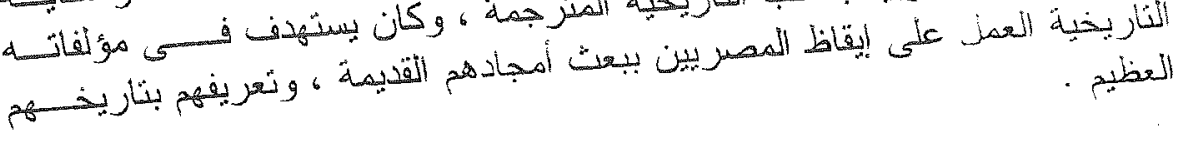

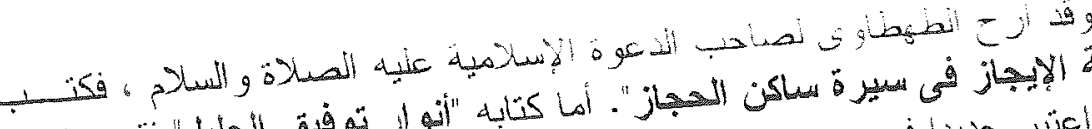

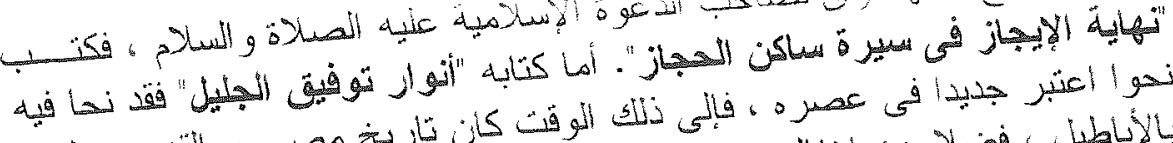

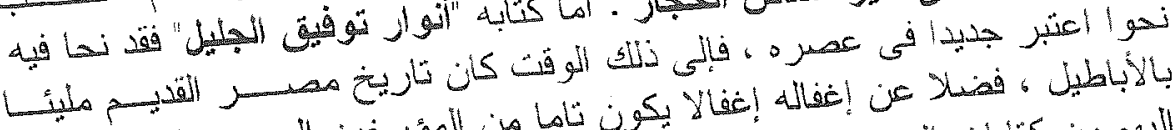

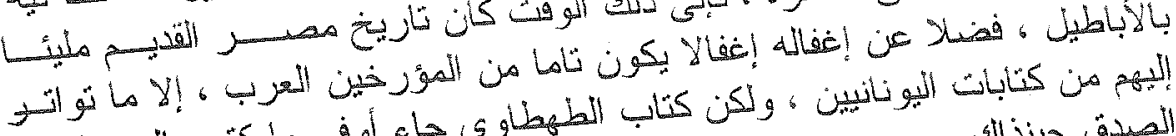

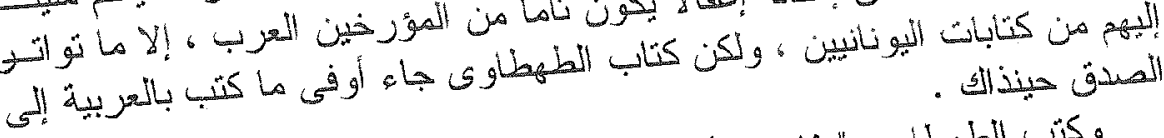

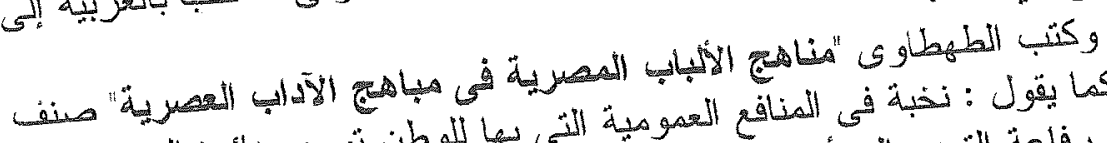

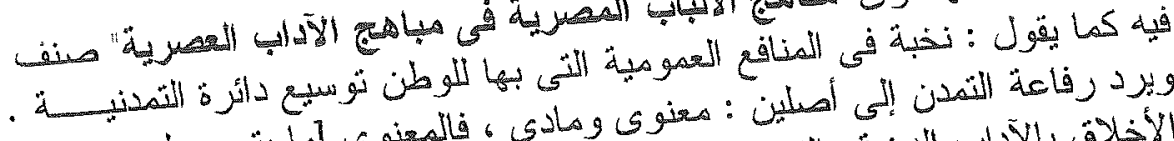

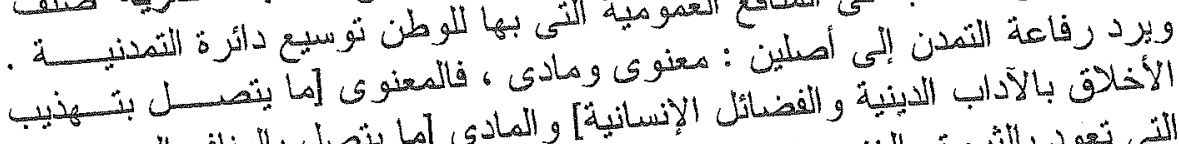

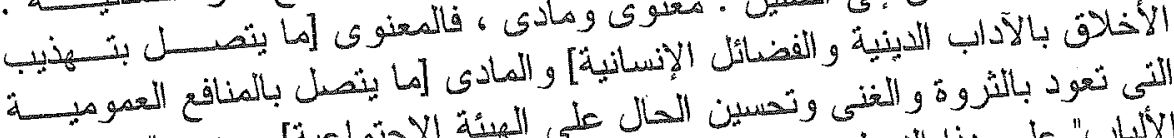

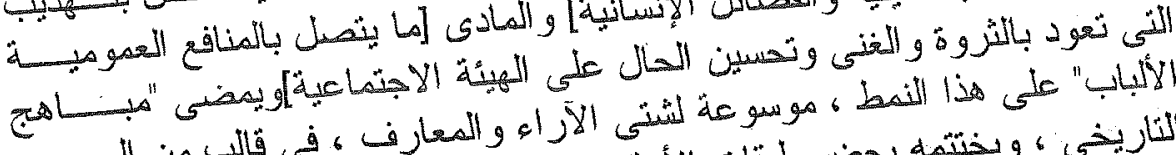

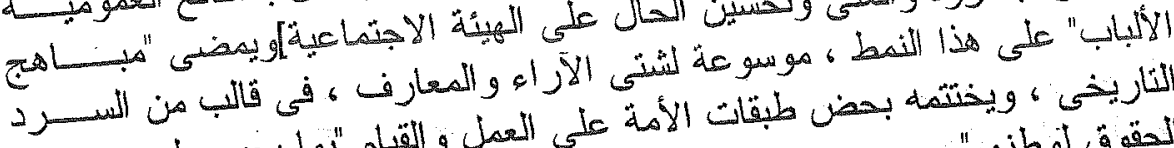

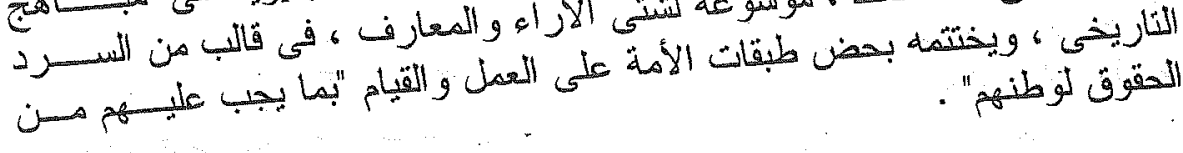

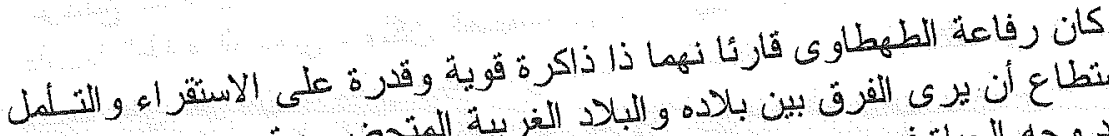

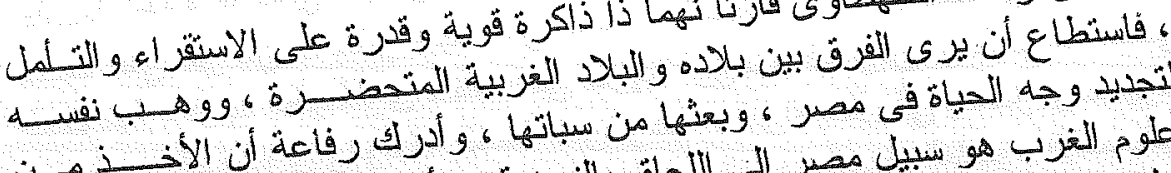

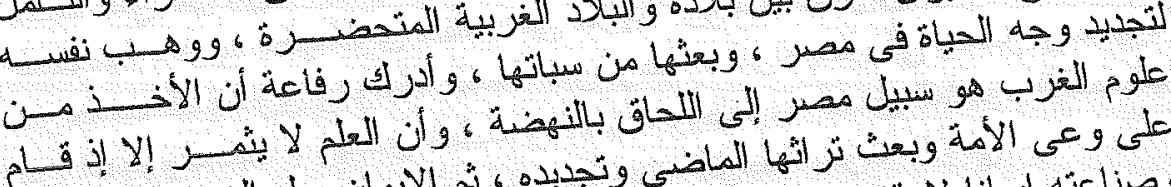

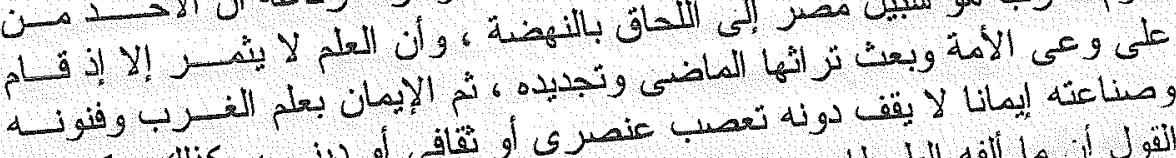

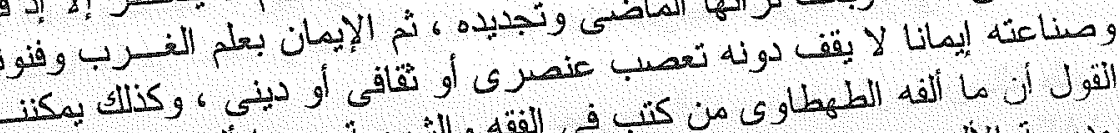

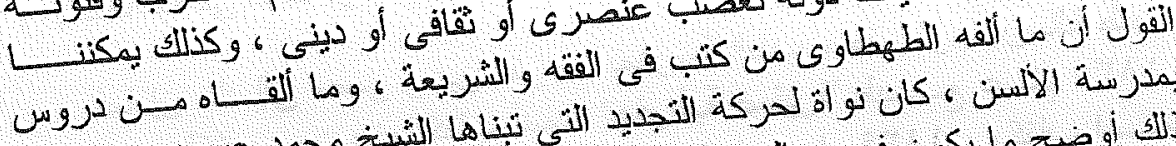

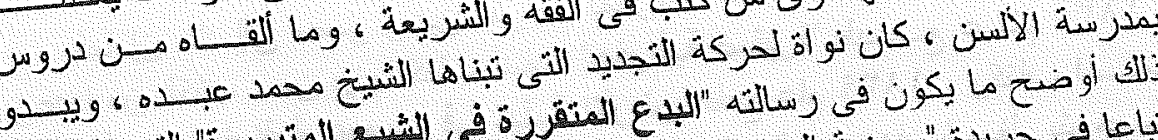

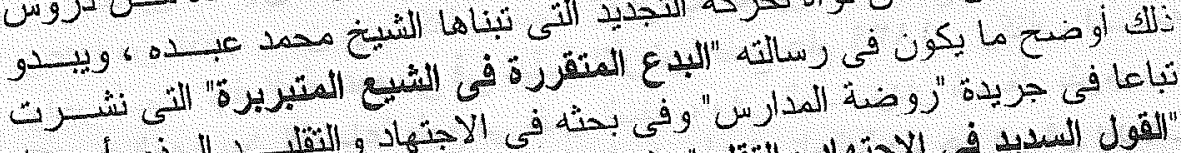

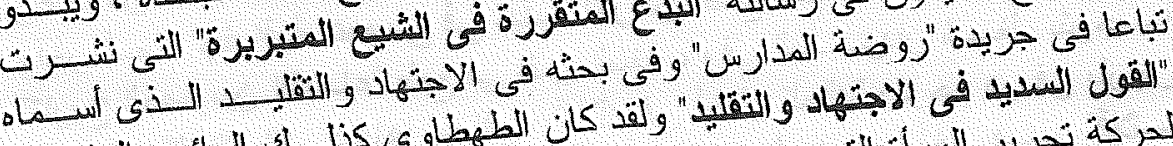

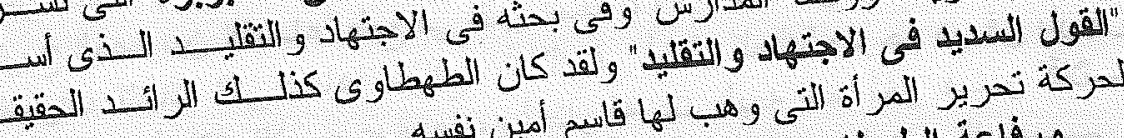

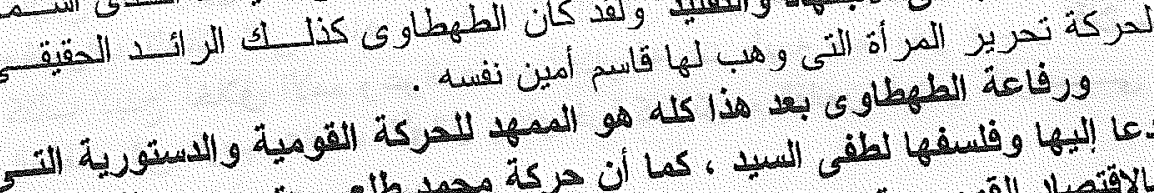

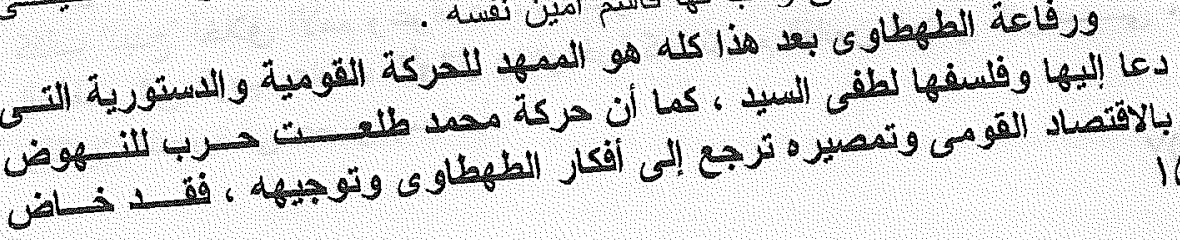




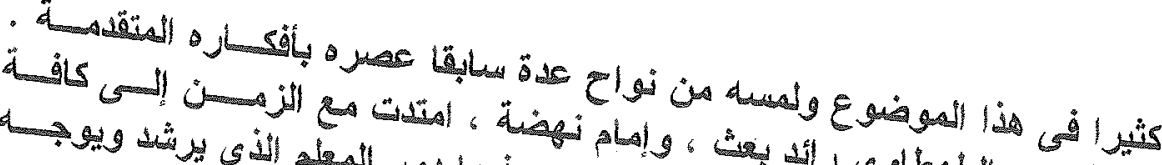

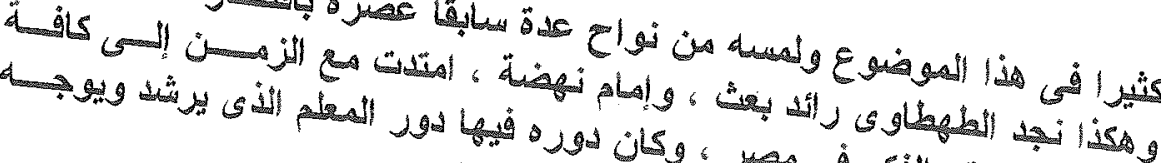

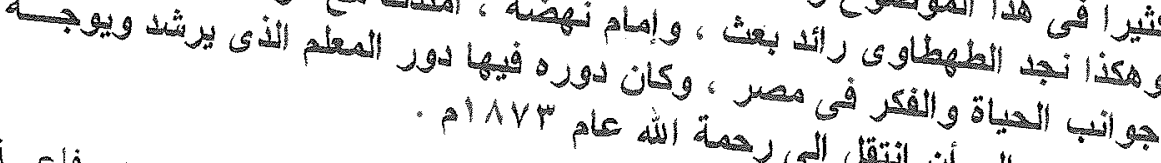

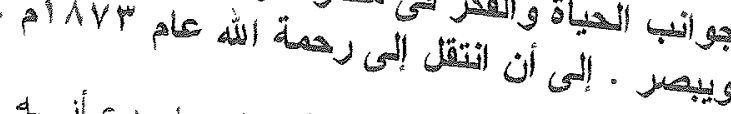

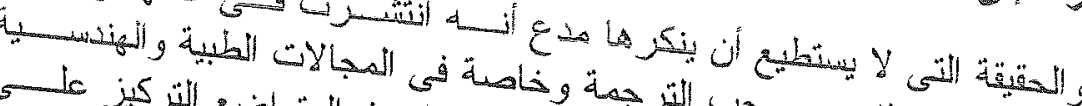

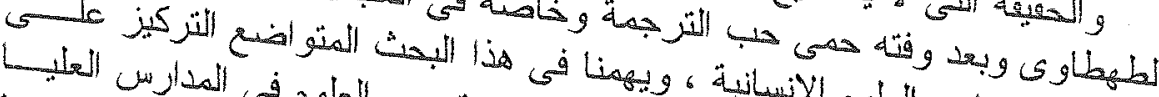

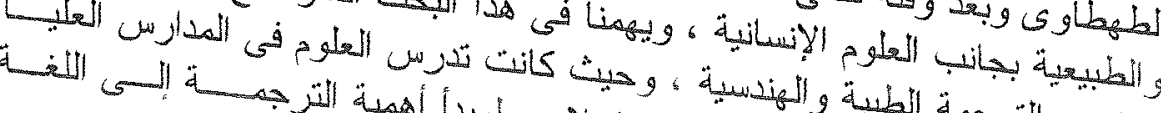

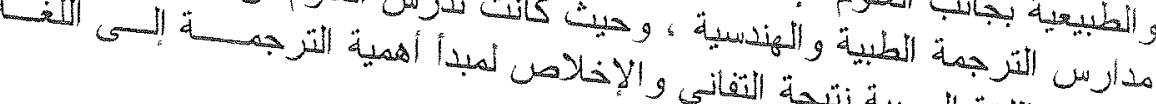

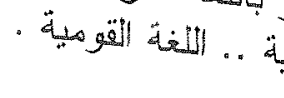

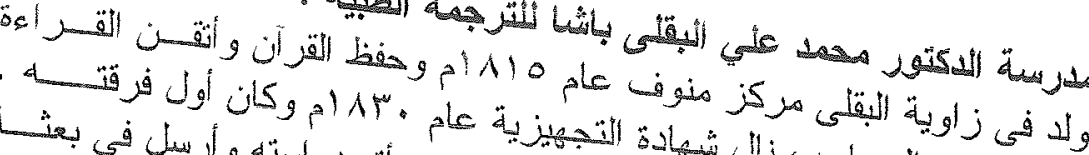

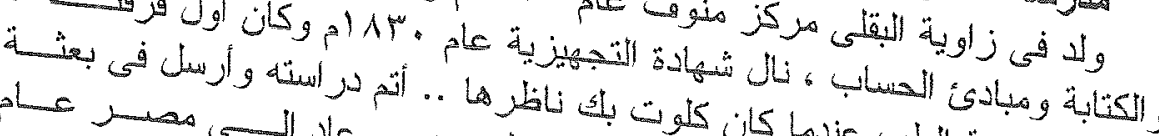

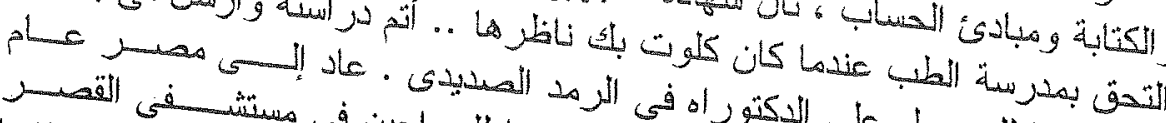

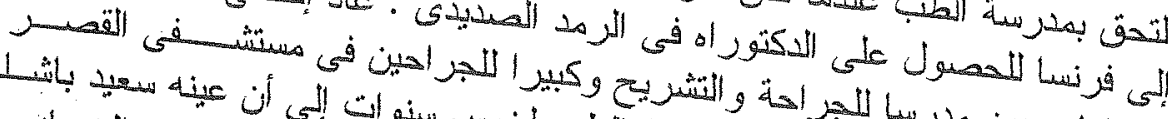

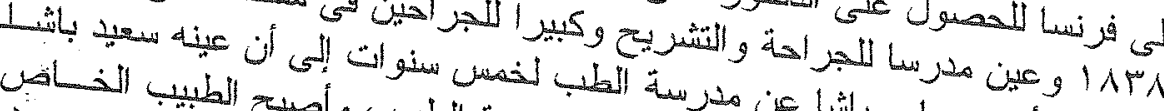

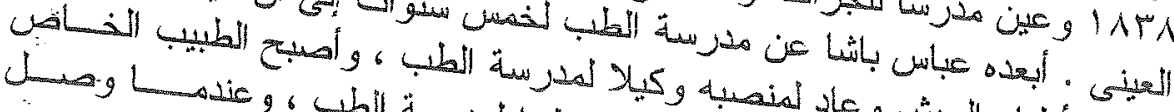

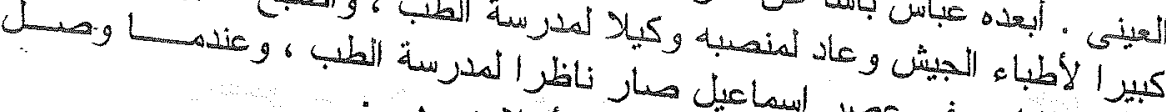

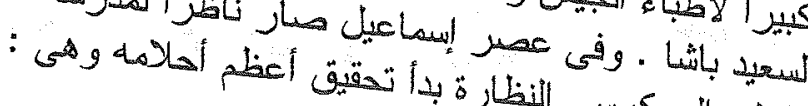$$
\text { - }
$$

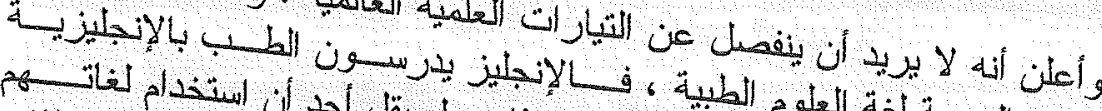

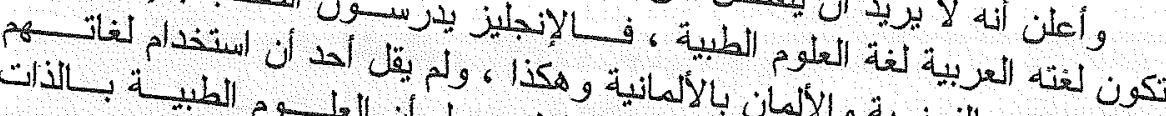

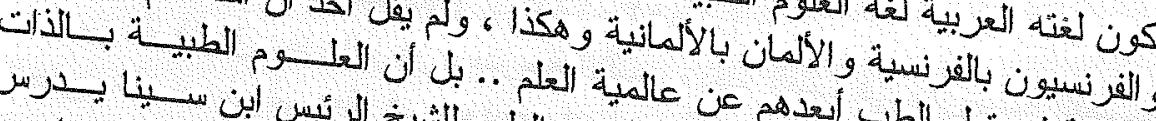

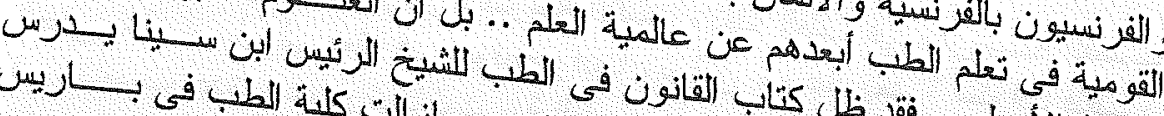

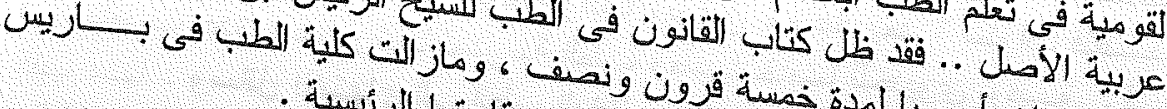

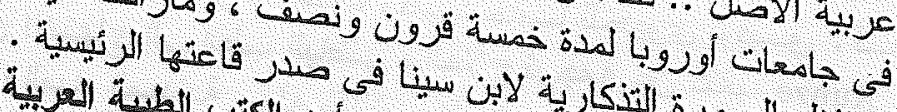

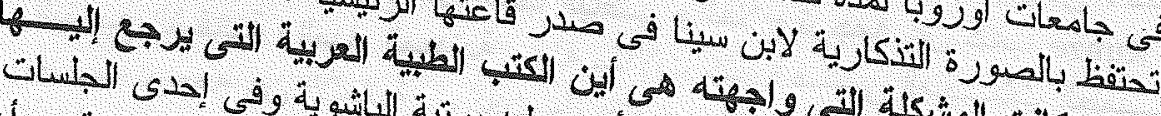

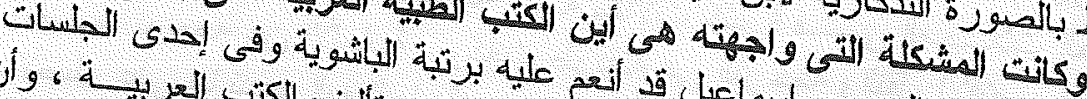

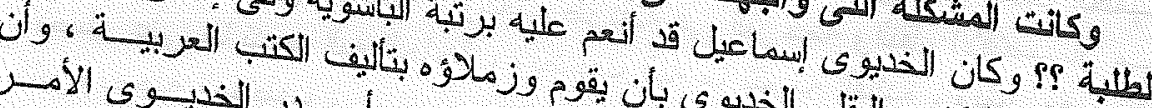

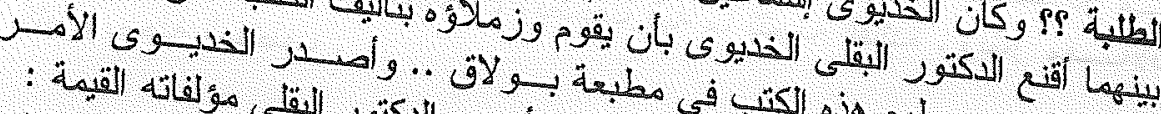

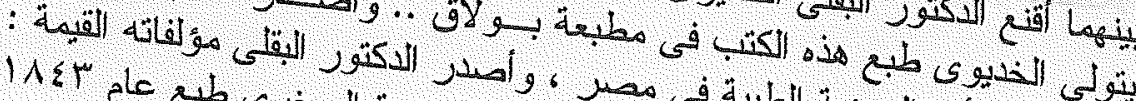
109

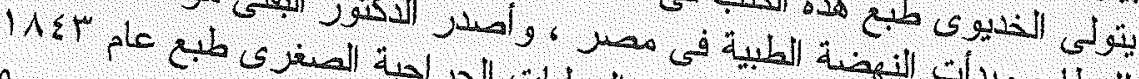

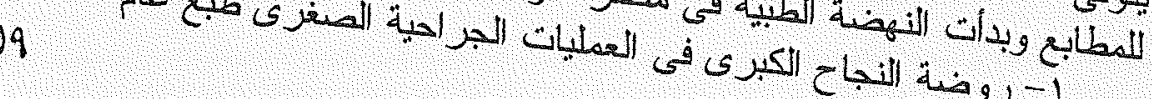




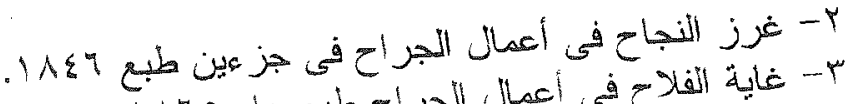

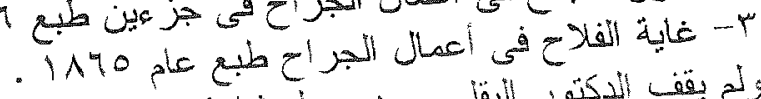

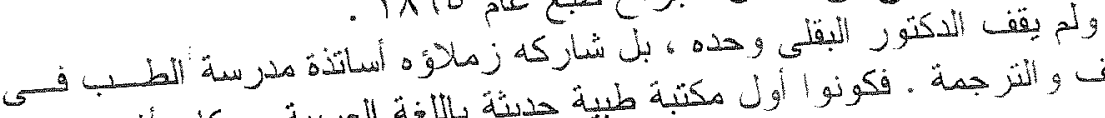

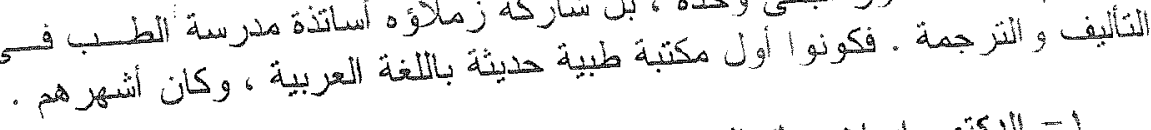

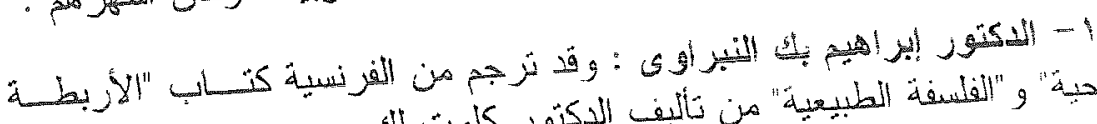

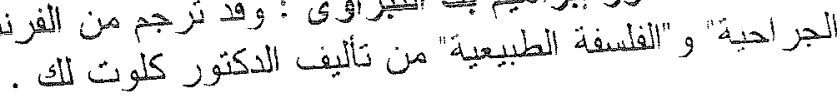

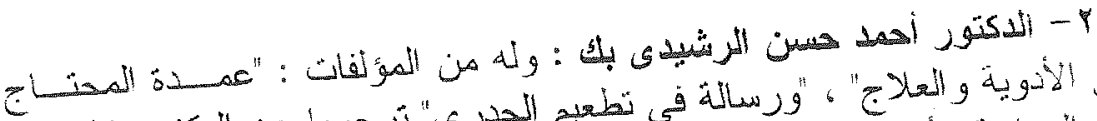

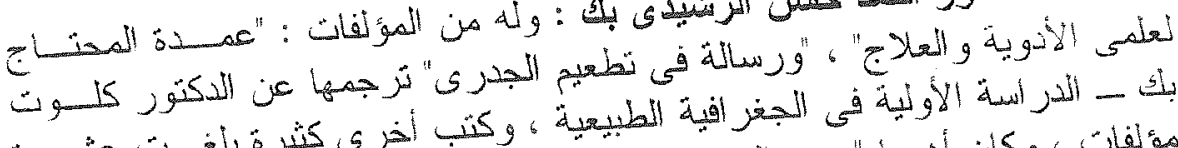

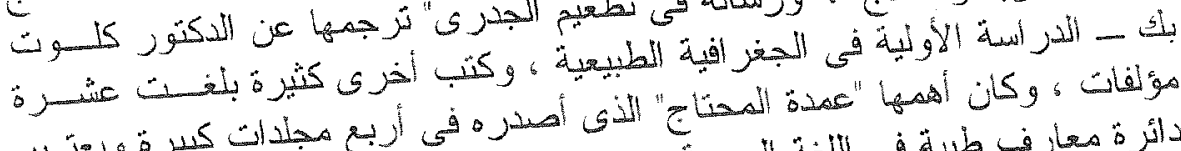

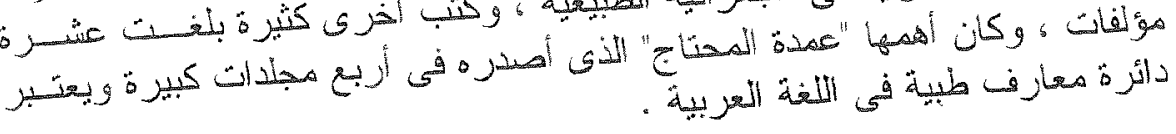

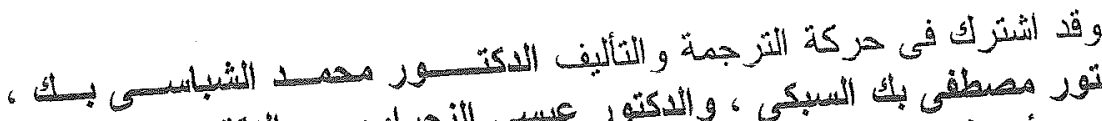

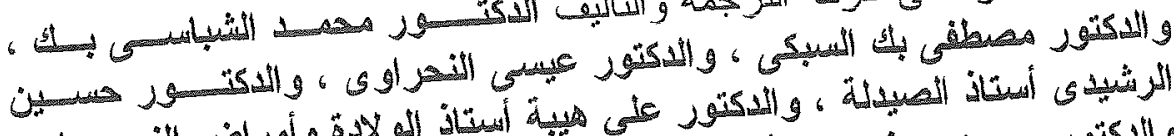

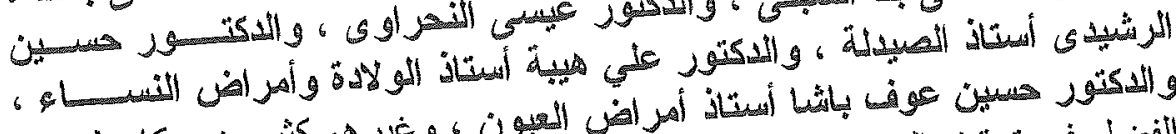

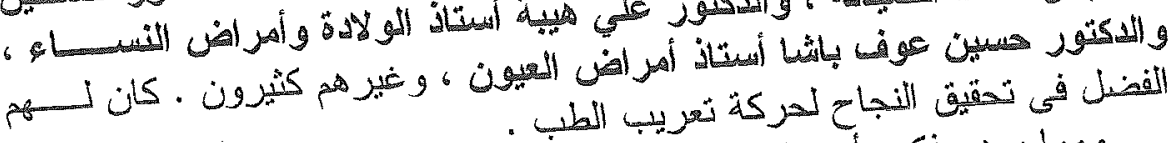

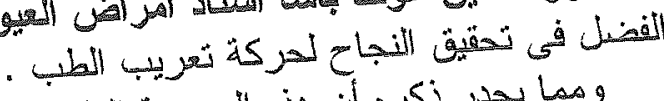

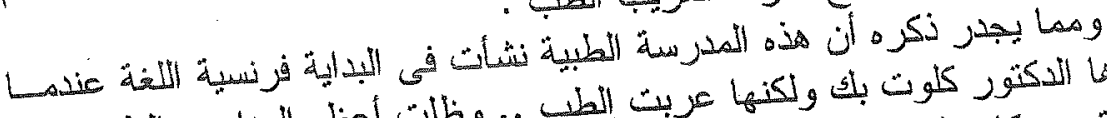

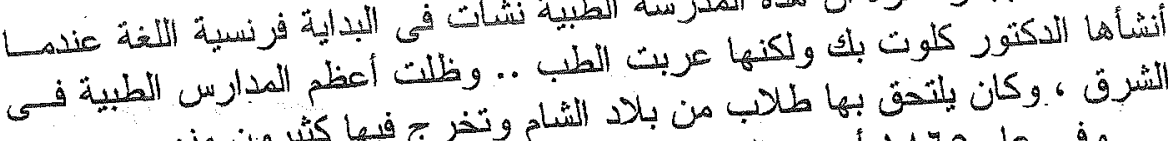

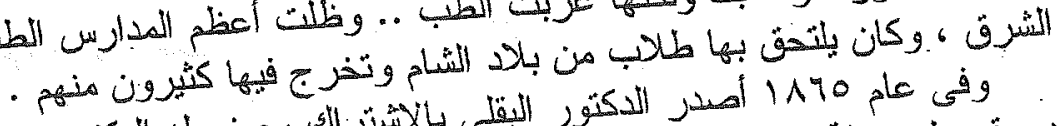

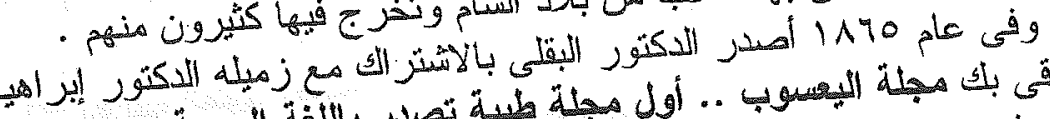

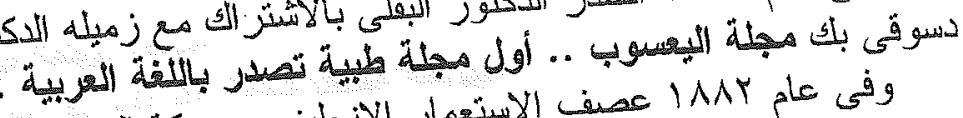

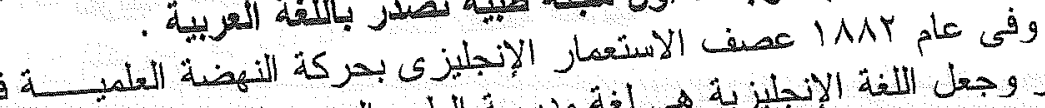

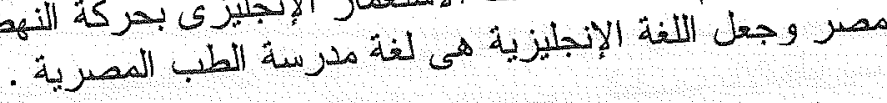

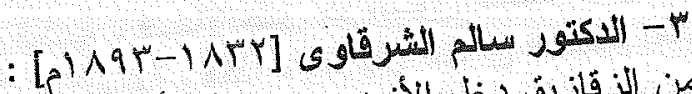

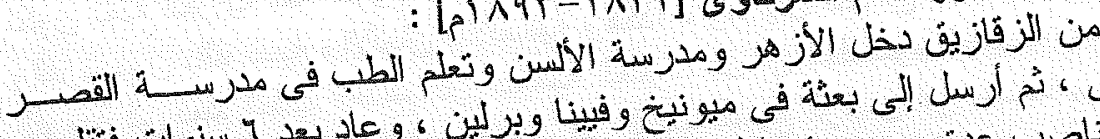

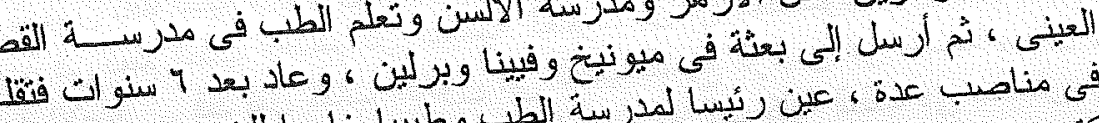

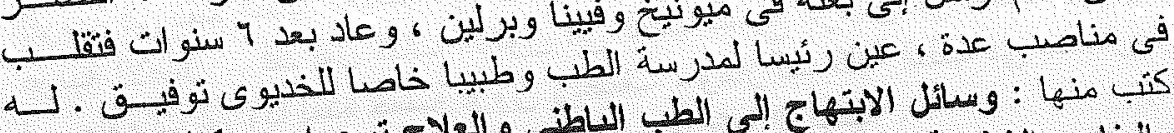

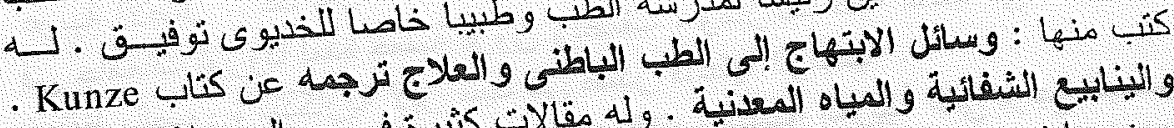

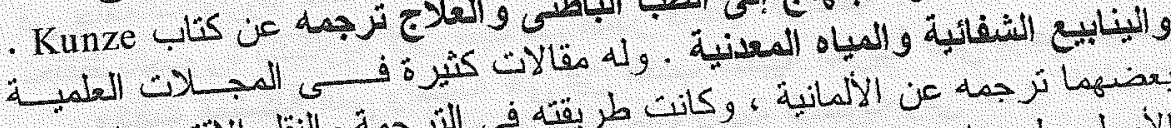

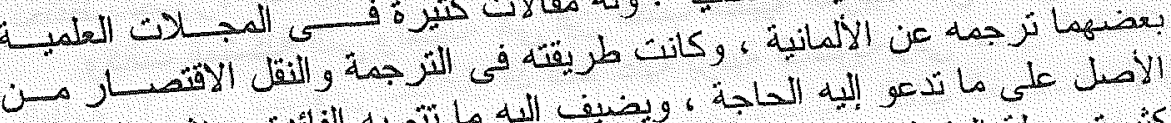

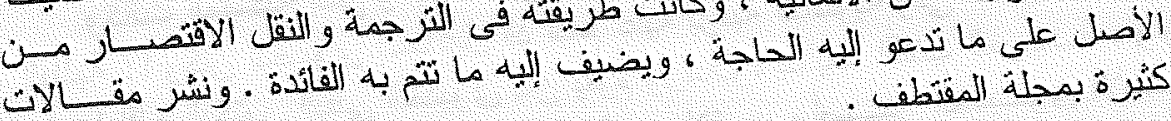




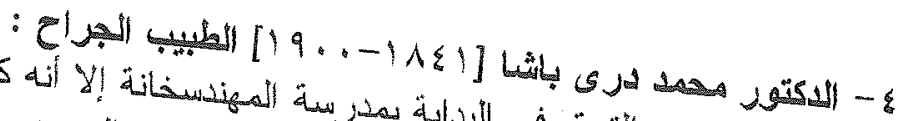

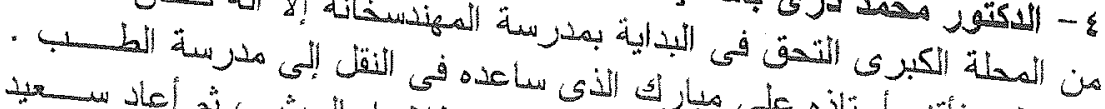

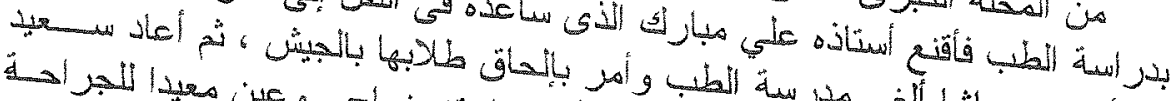

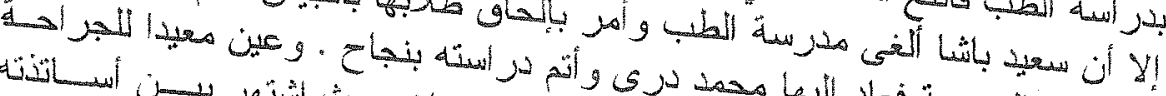

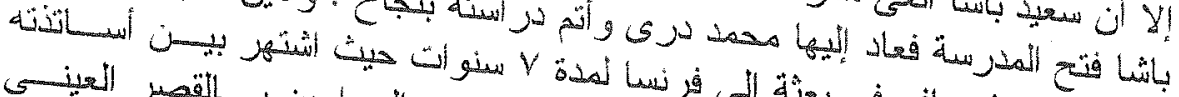

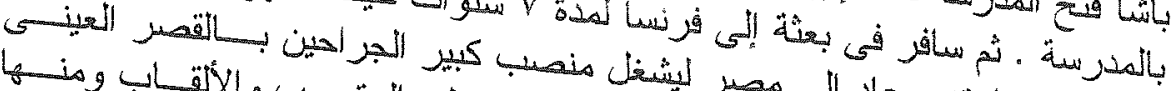

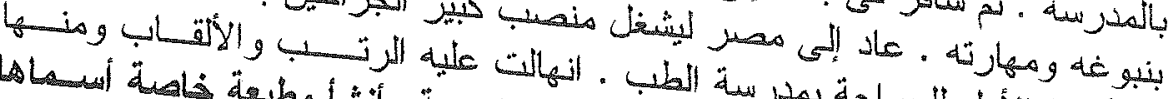

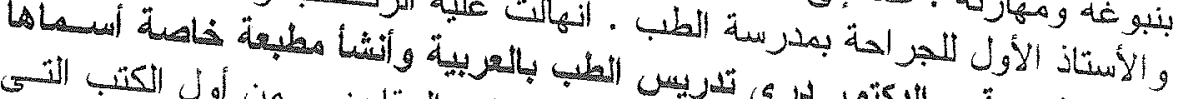

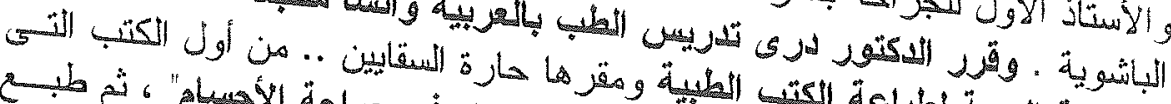

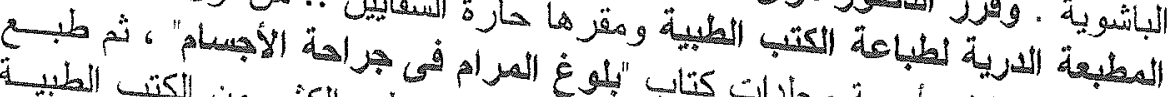

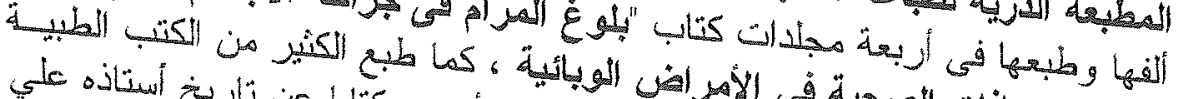

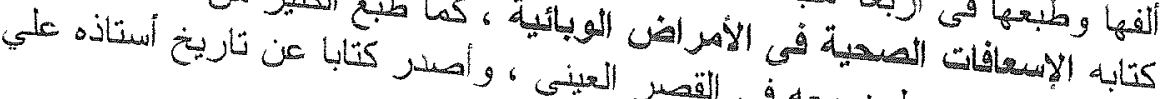

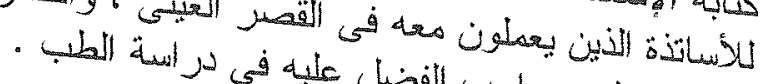

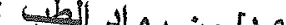

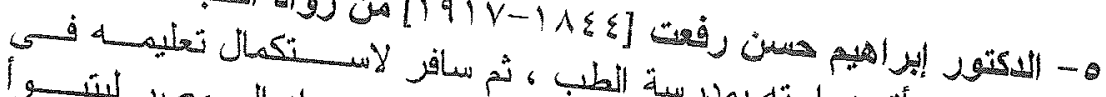

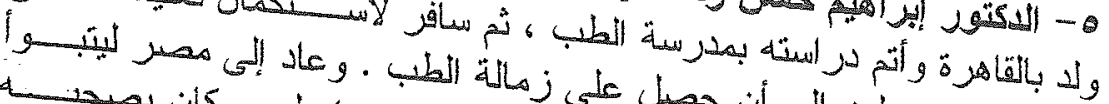

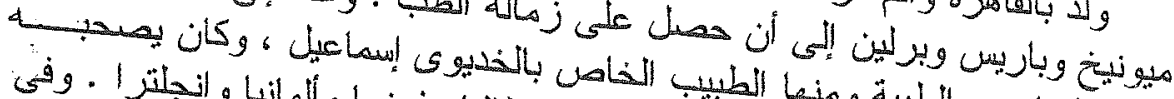

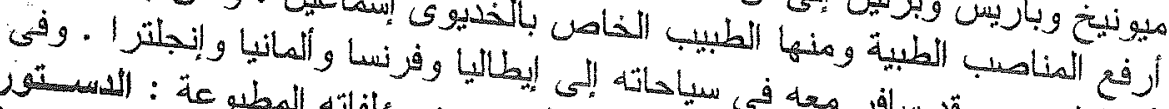

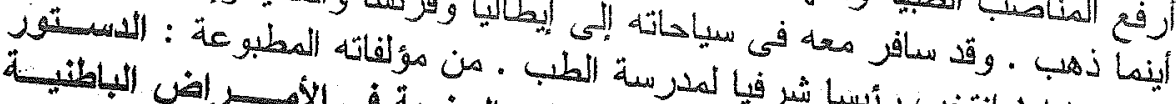

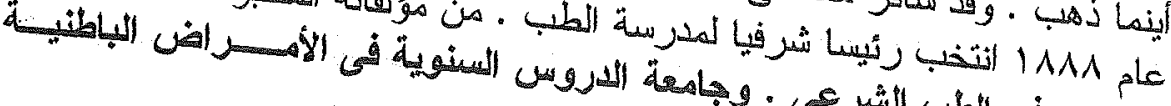

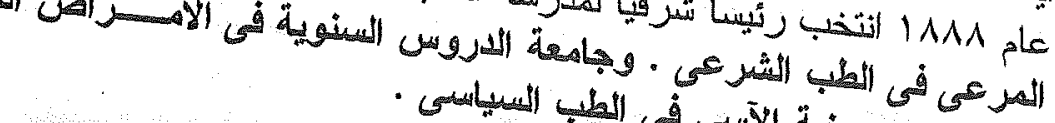

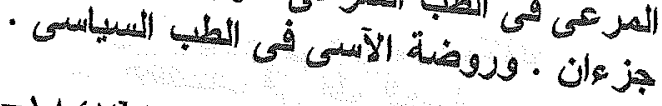

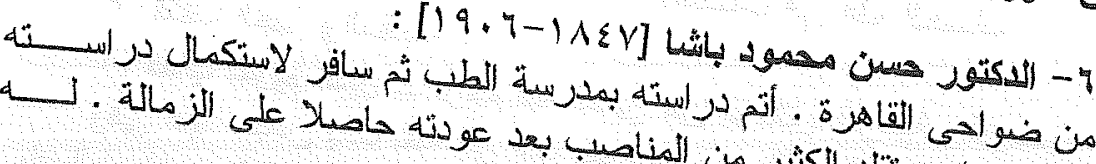

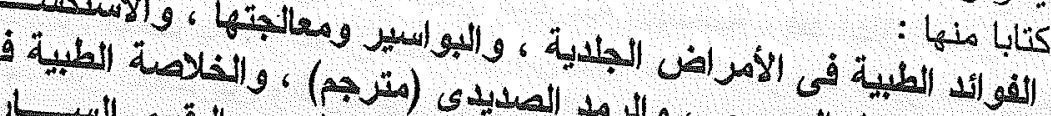

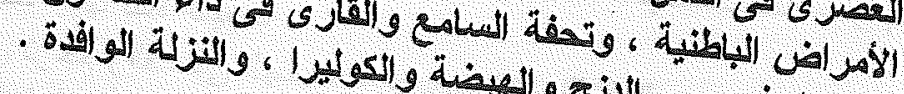

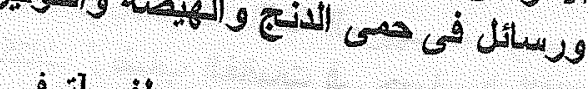

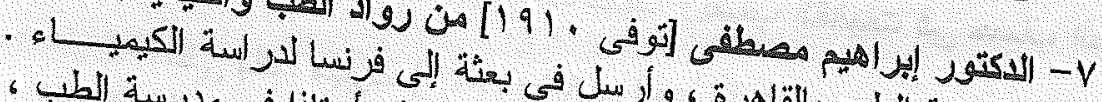

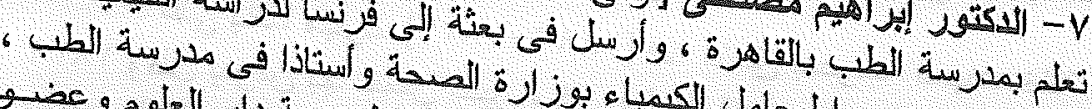

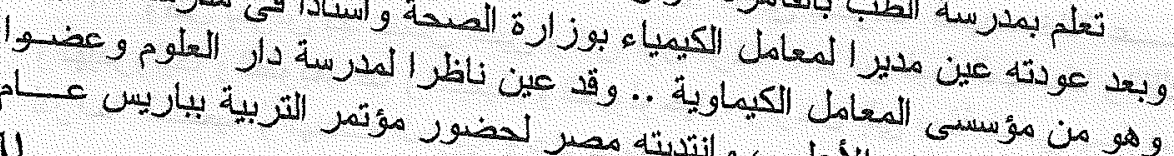
171

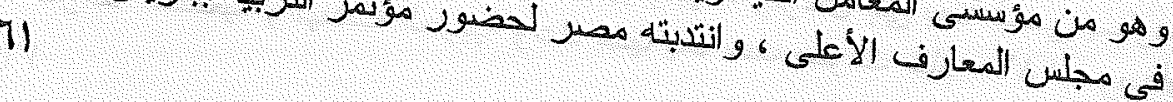




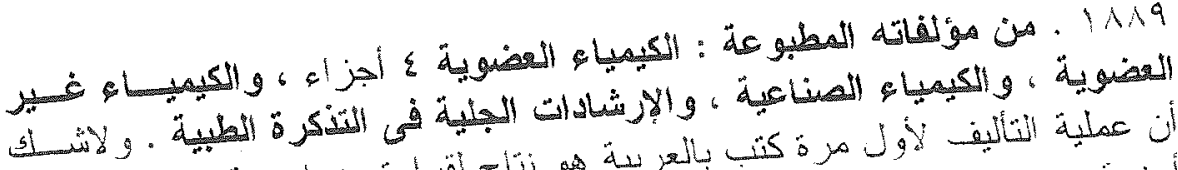

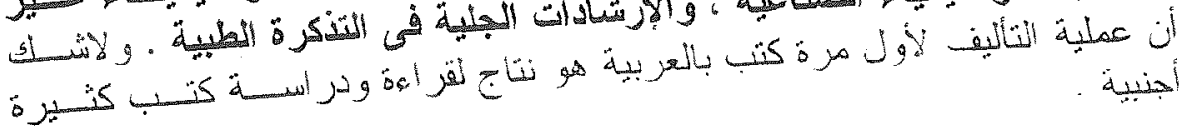

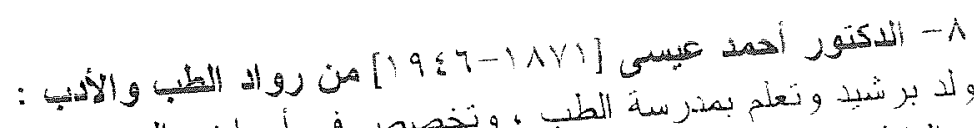

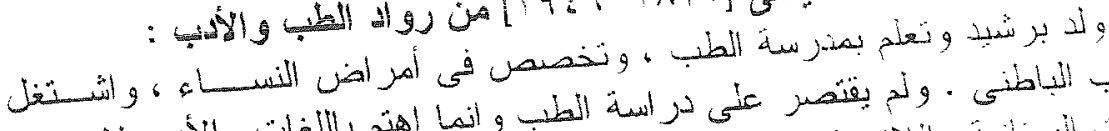

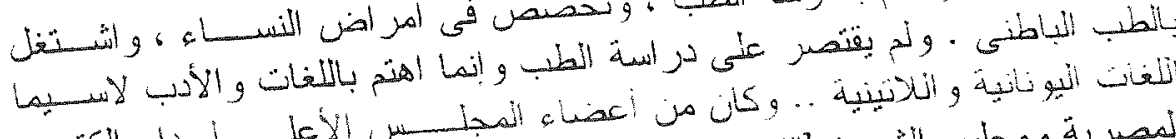

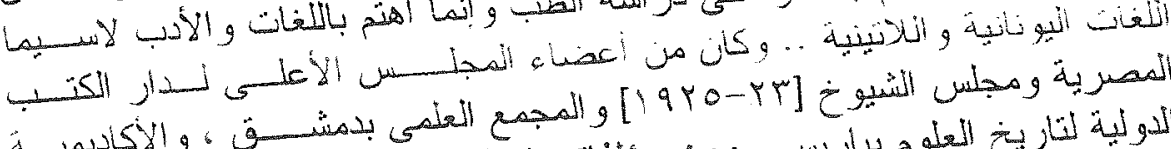

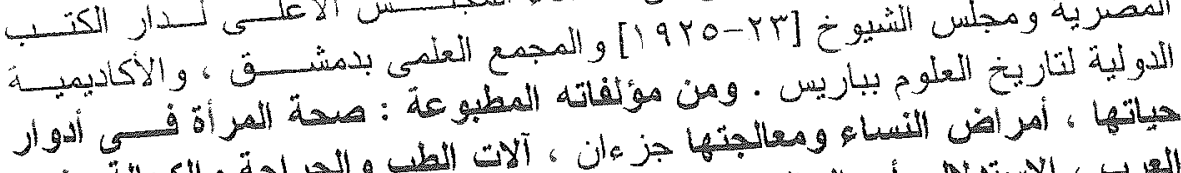

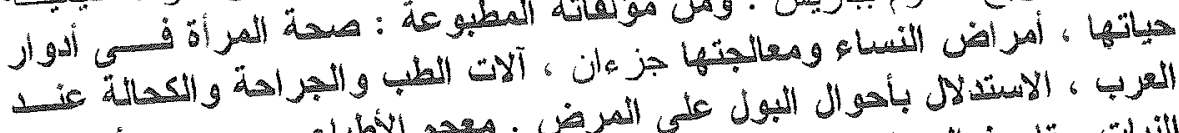

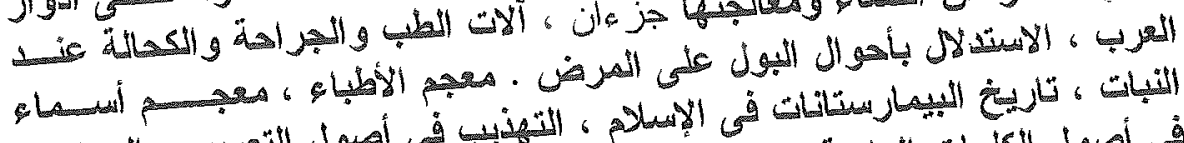

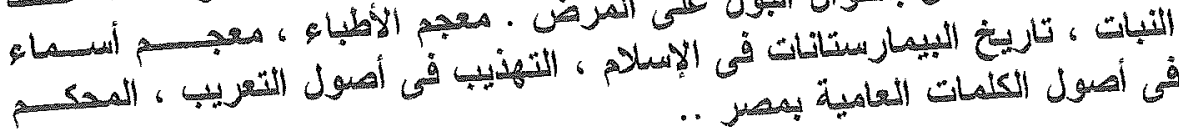

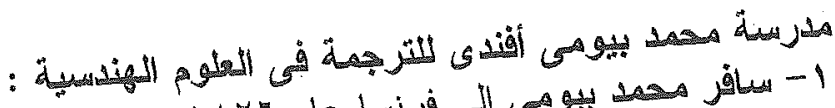

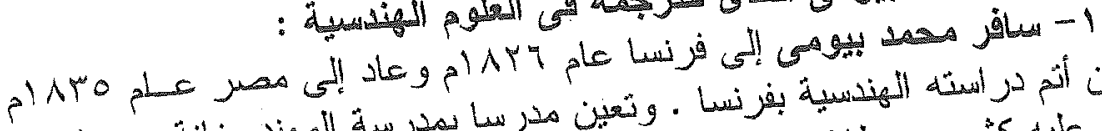

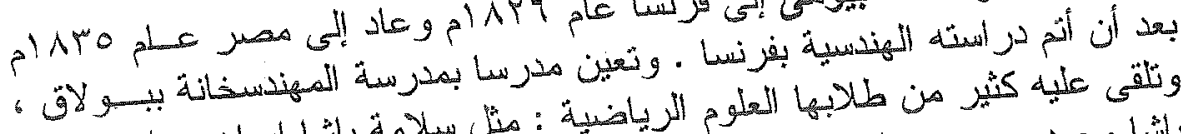

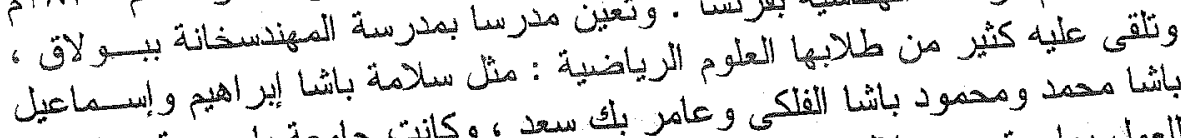

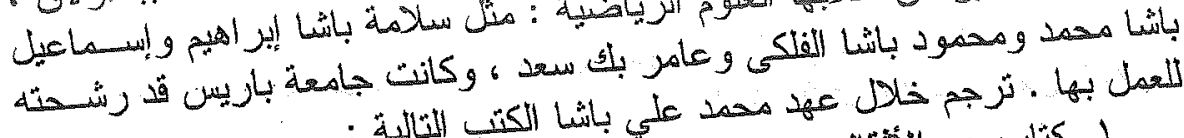

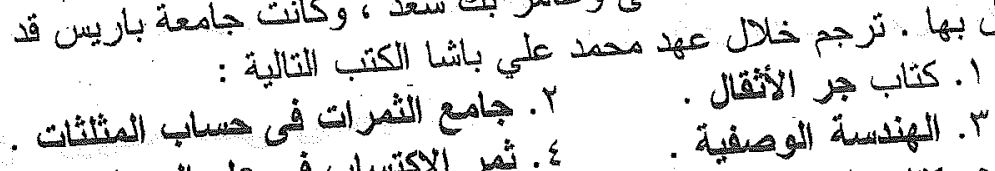

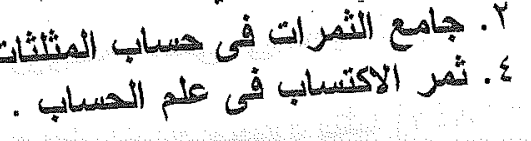

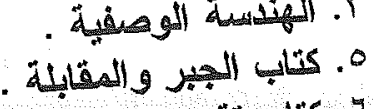

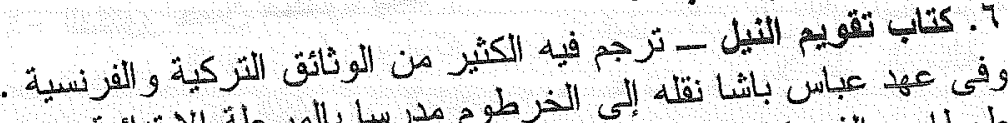

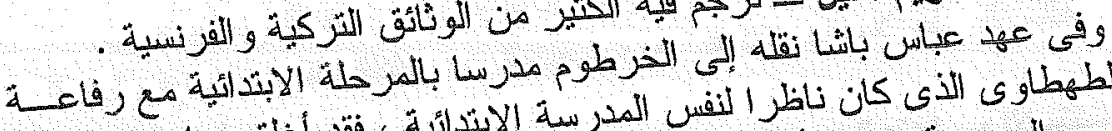

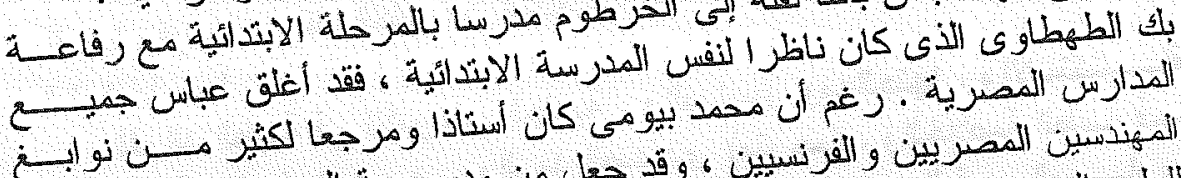

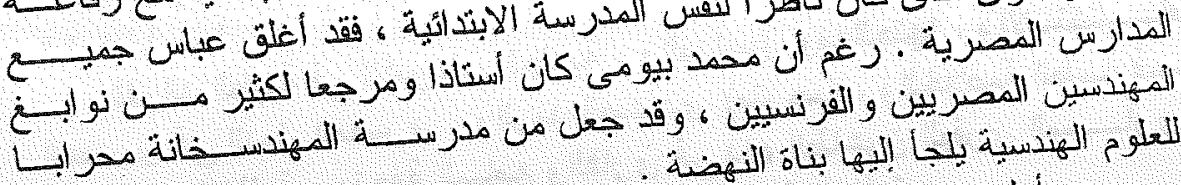

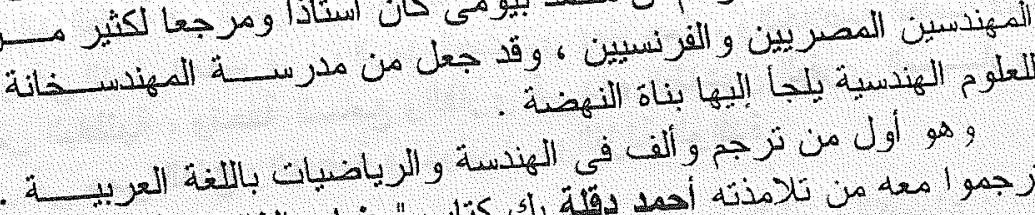

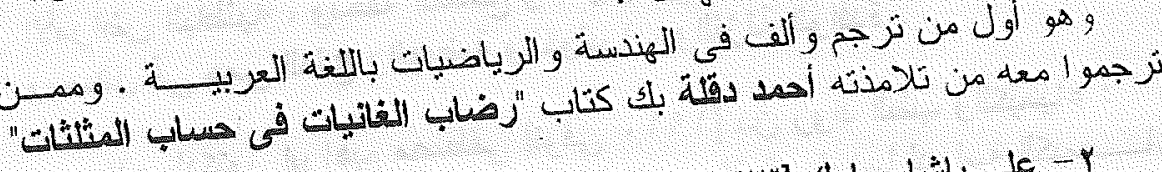

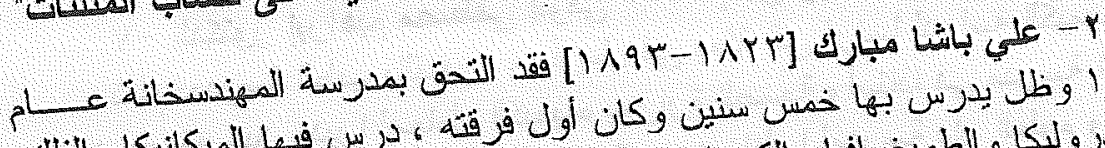

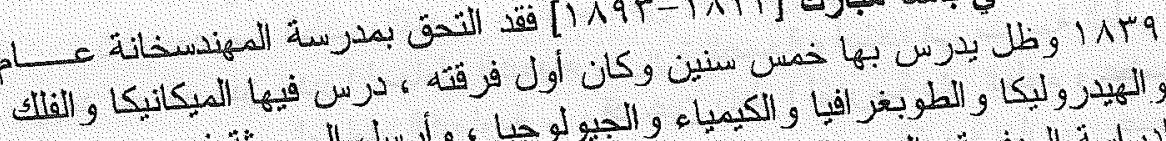

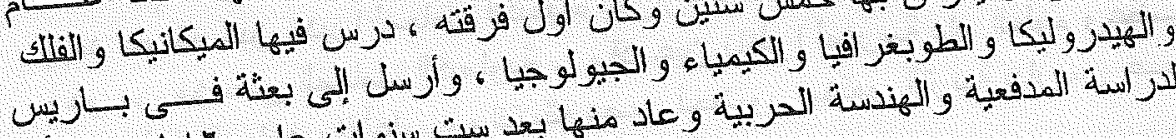

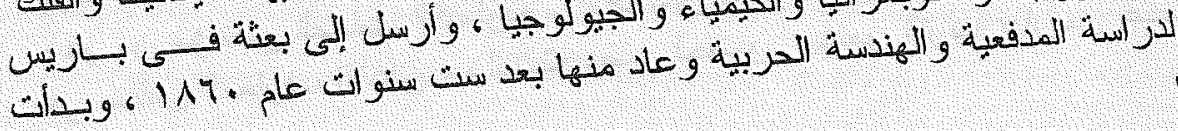




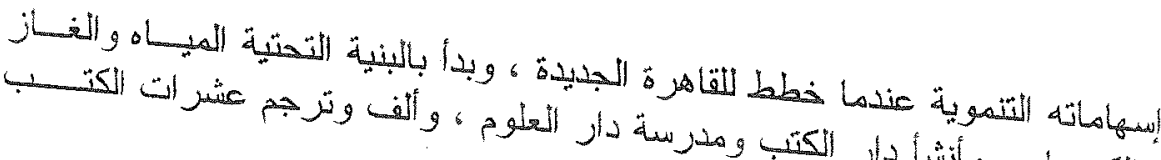

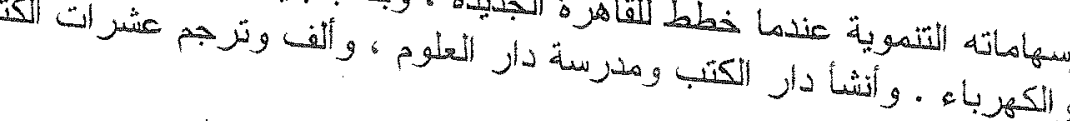

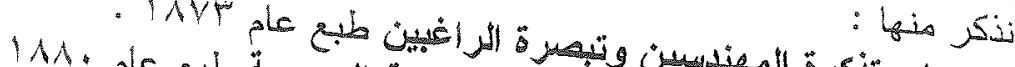

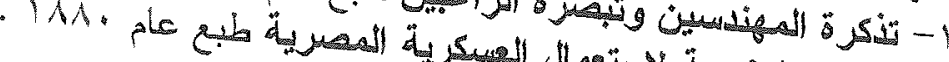

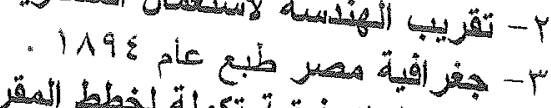

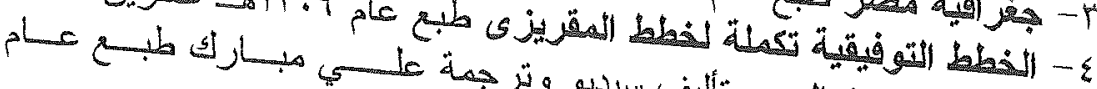

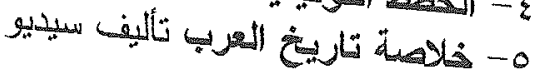

$\rightarrow 1+9$

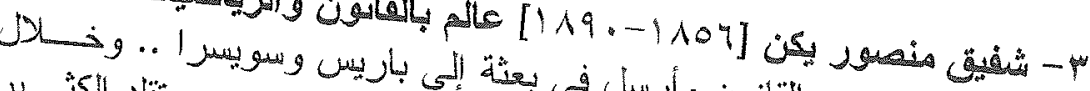

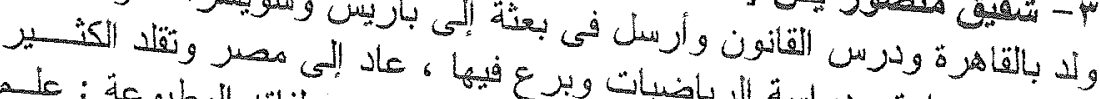

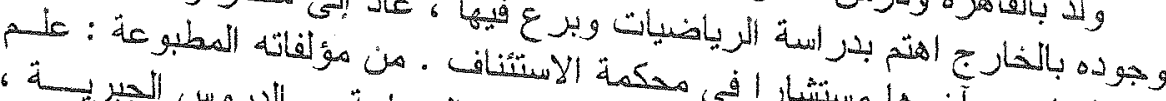

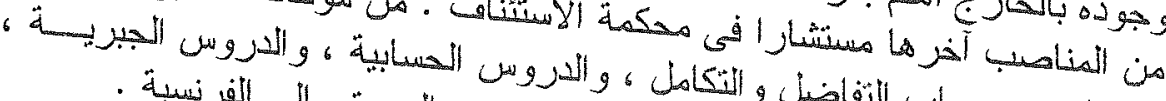

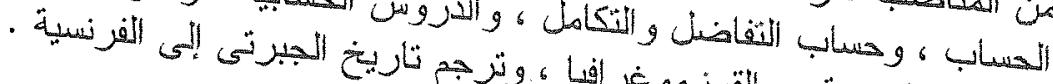

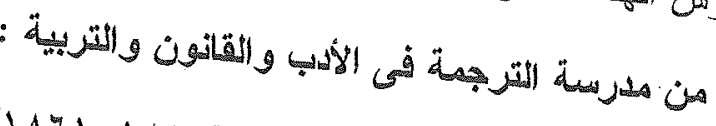

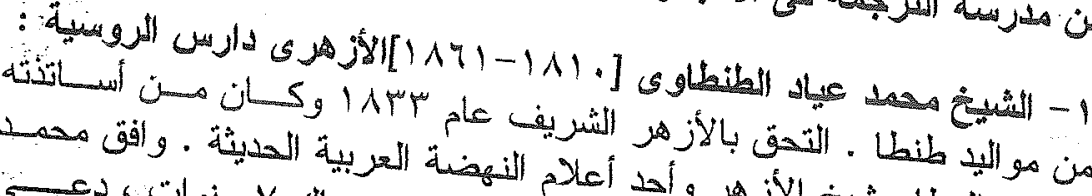

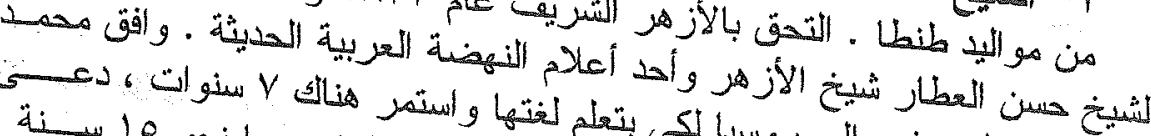

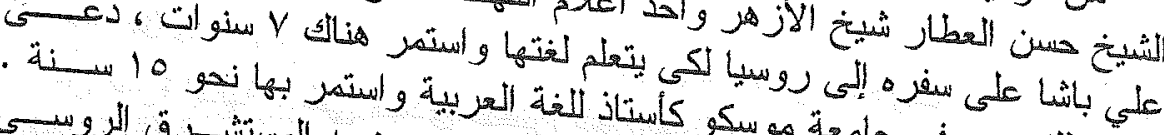

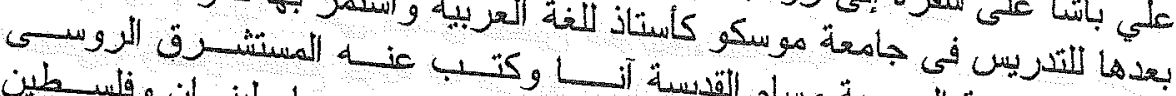

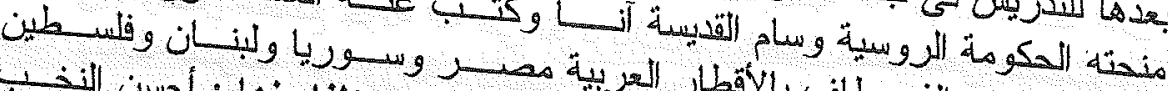

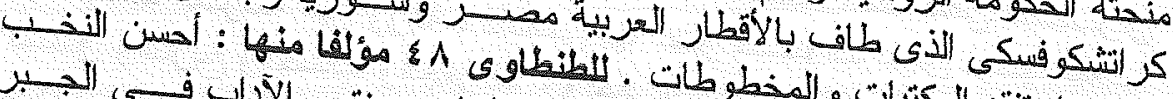

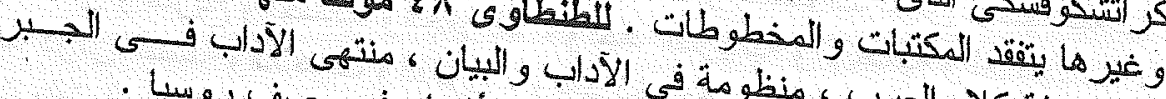

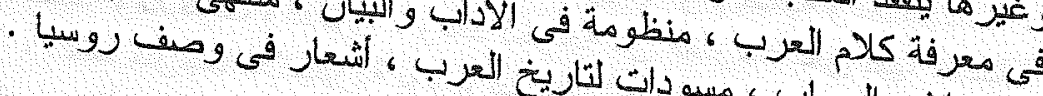
:

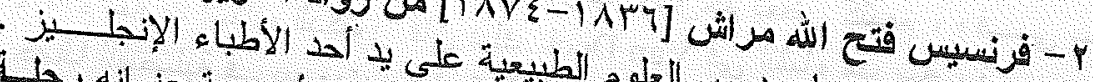

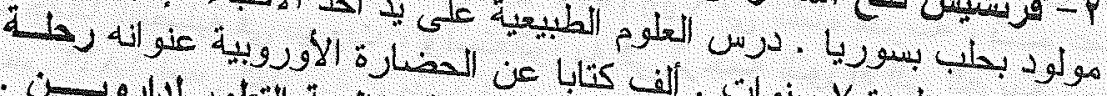

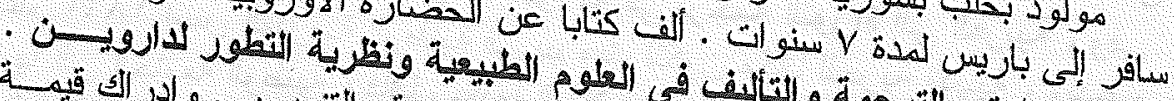

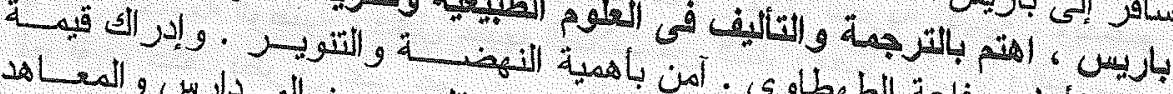

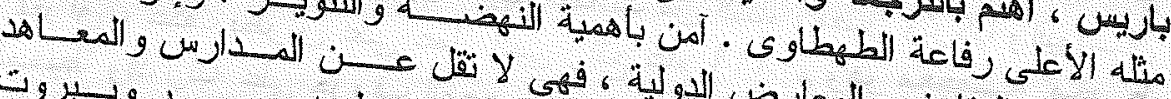

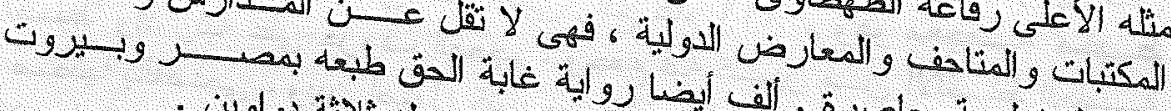

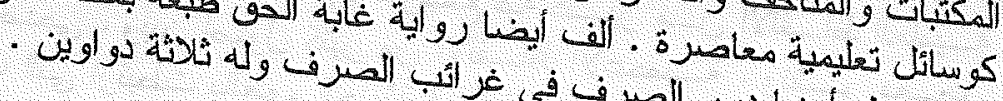




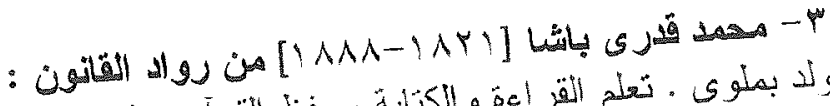

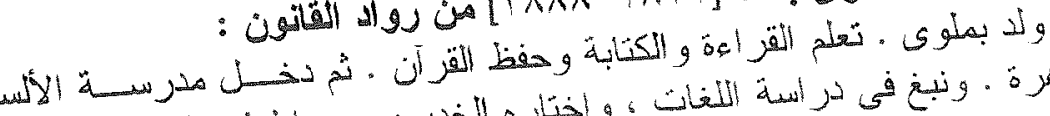

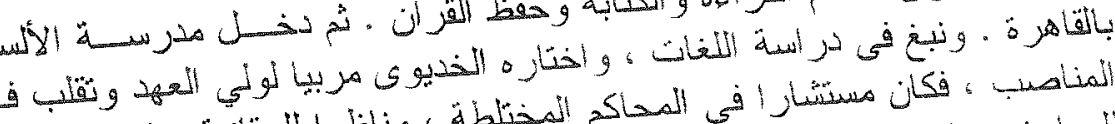

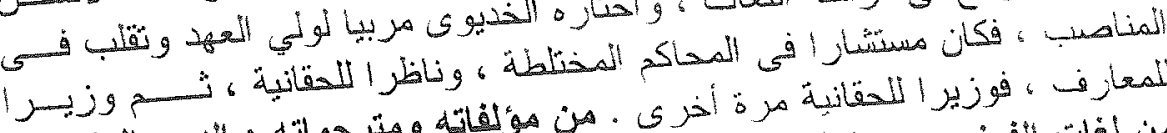

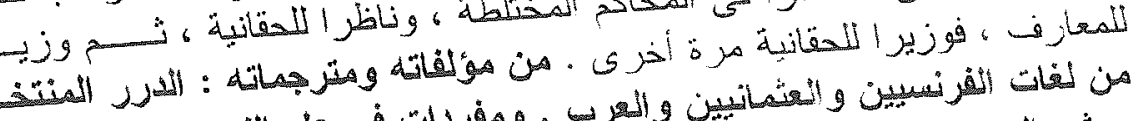

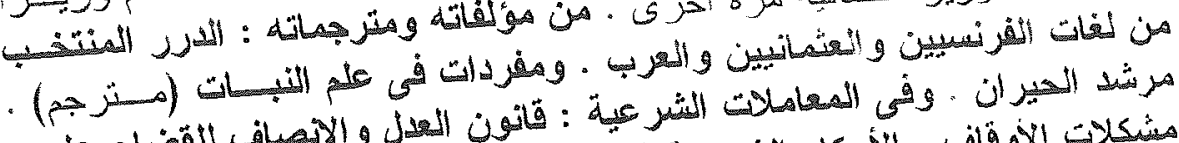

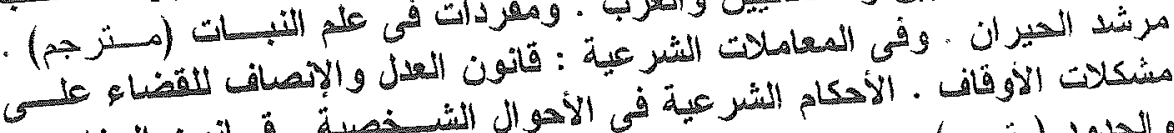

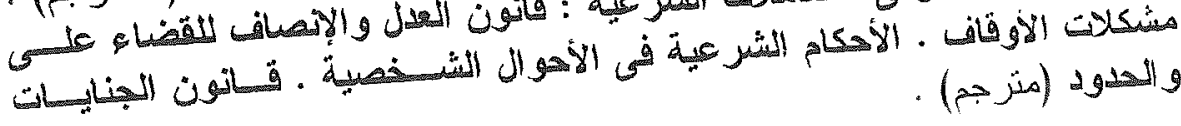

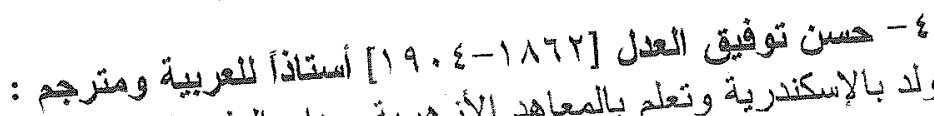

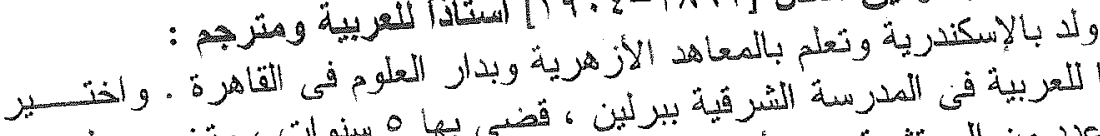

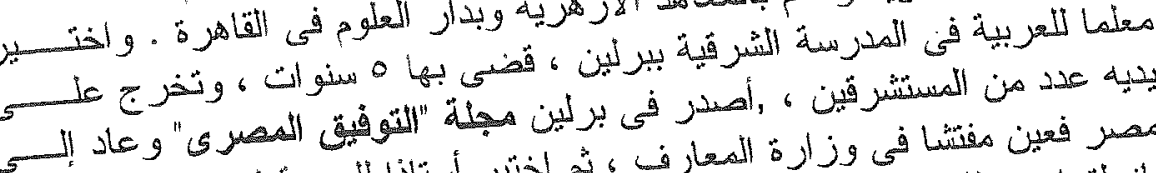

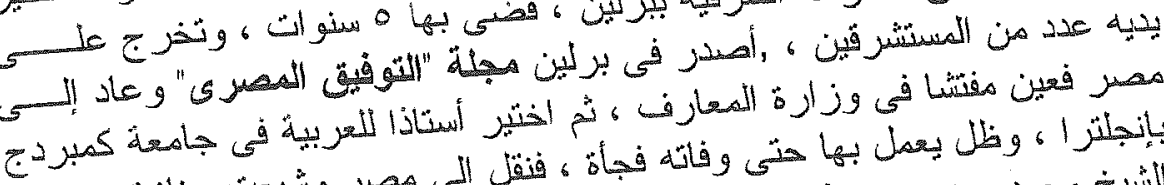

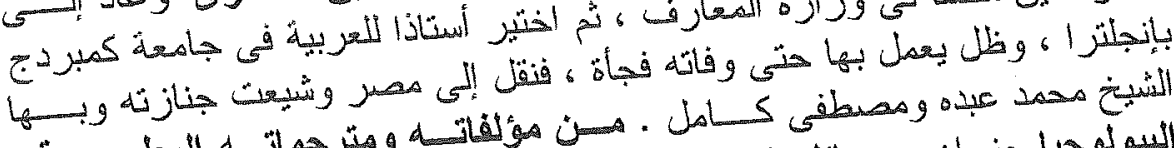

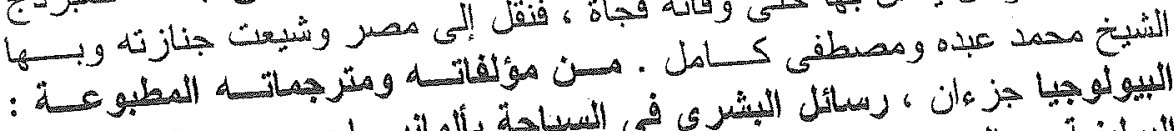

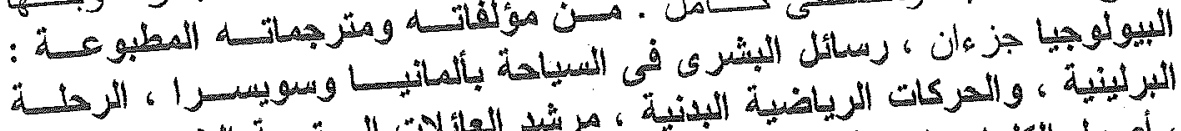

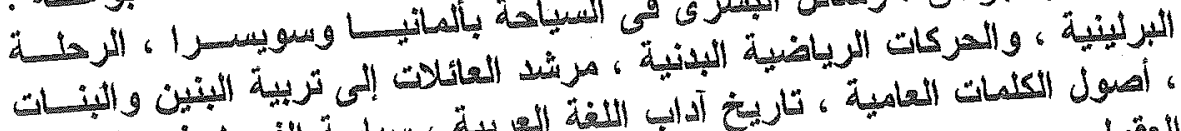

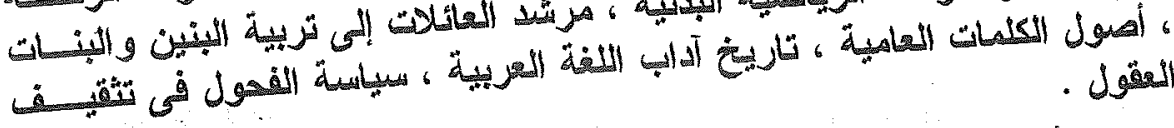
الأفقول .

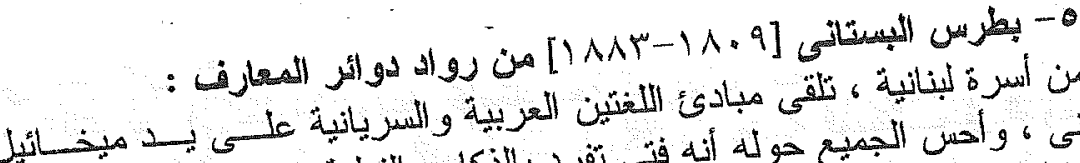

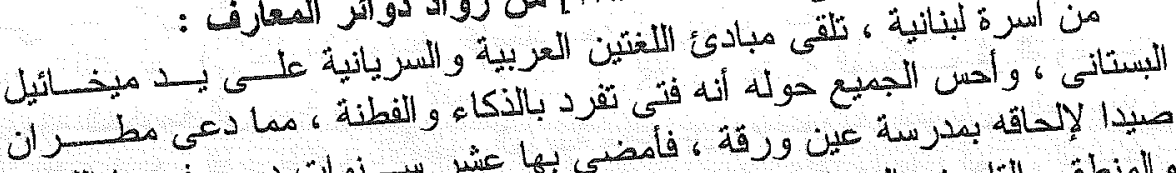

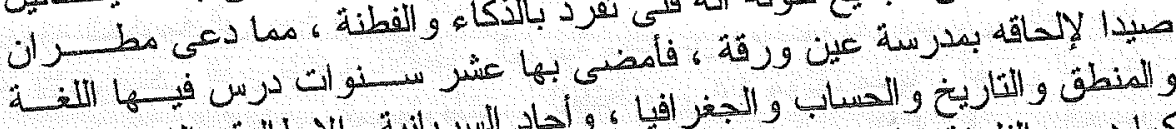

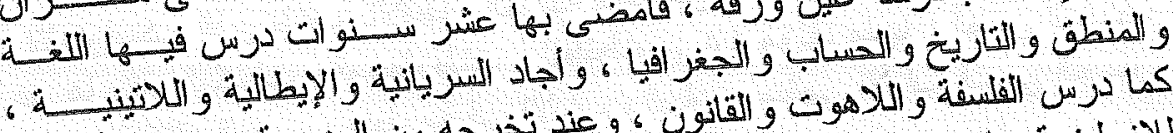

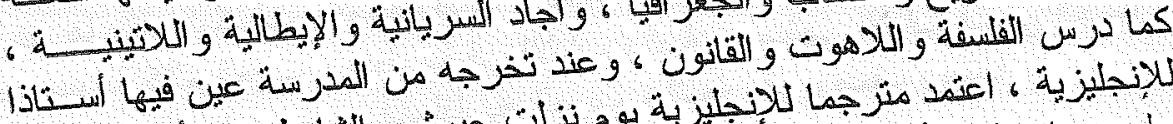

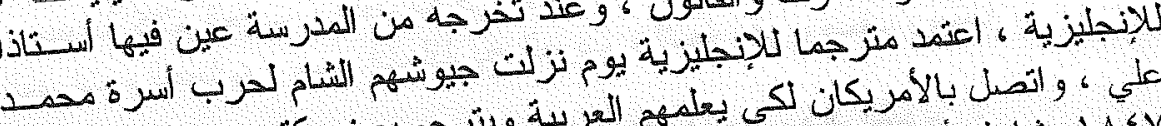

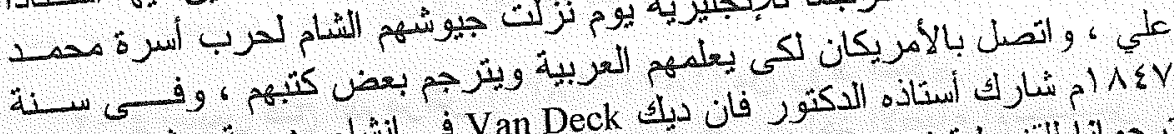

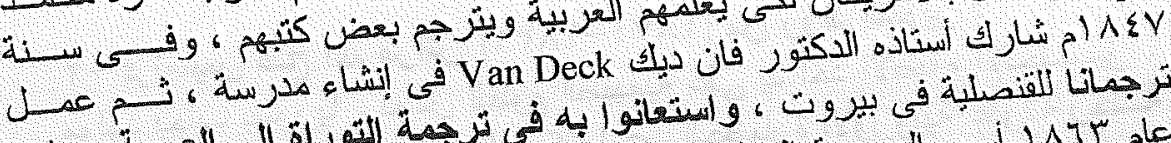

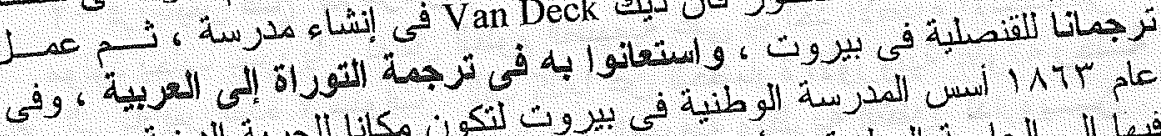

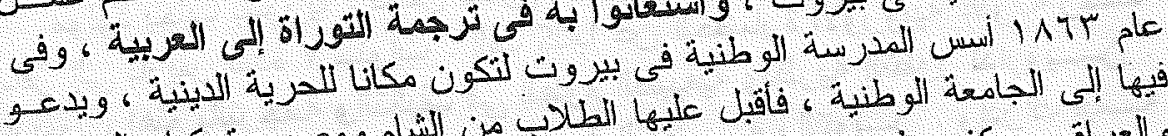

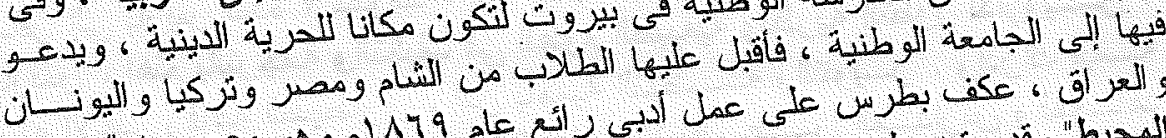

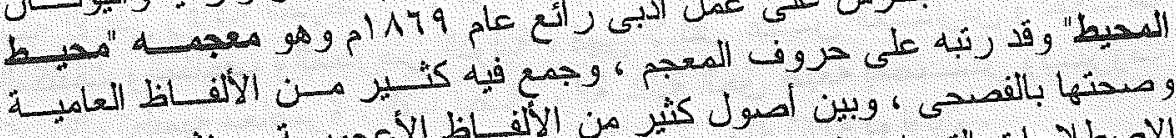

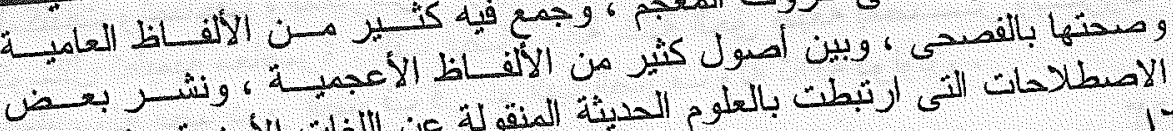

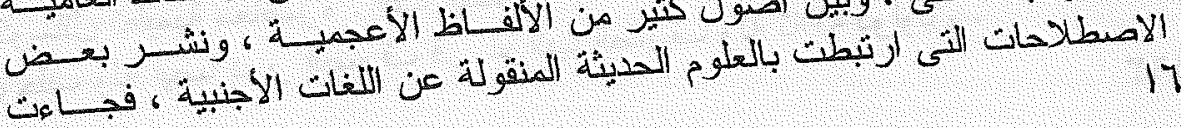




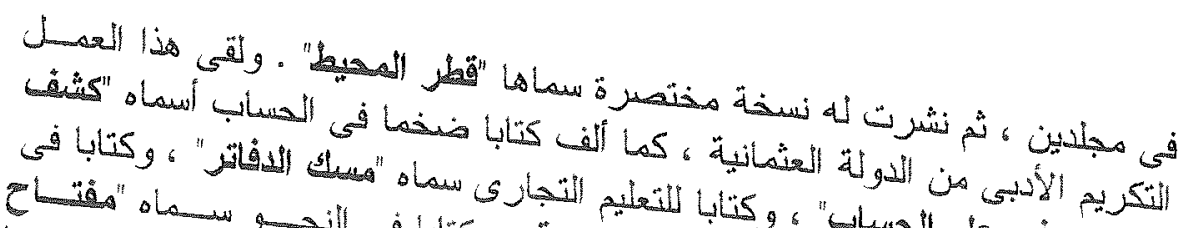

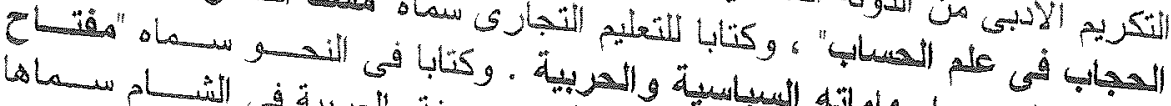

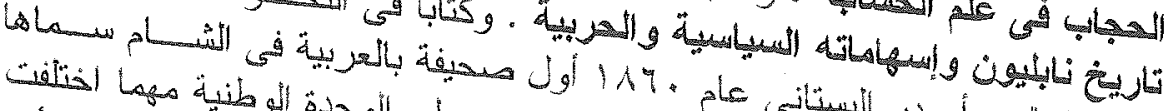

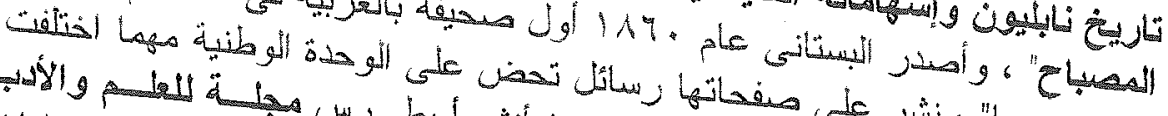

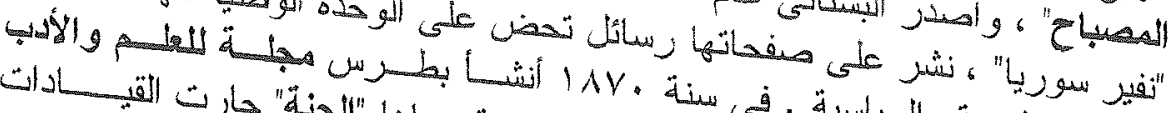

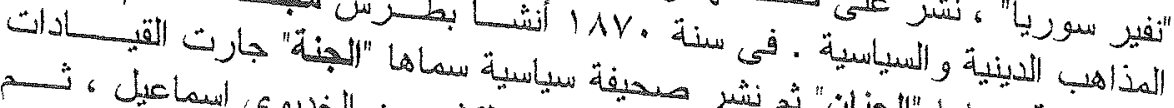

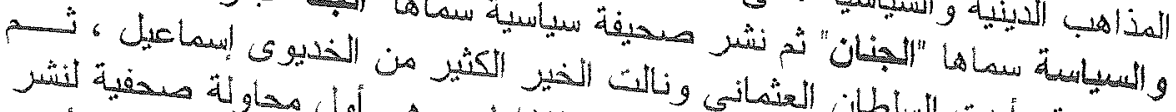

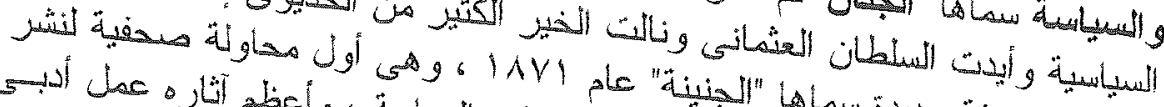

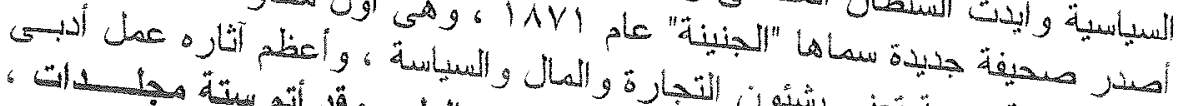

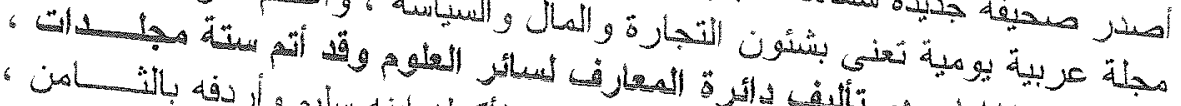

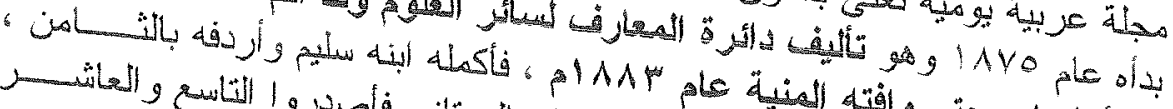

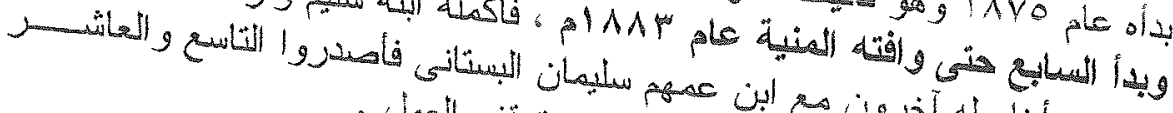

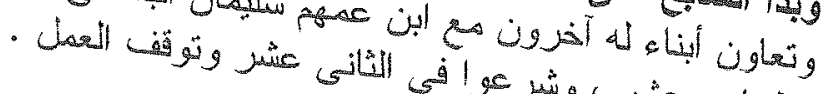

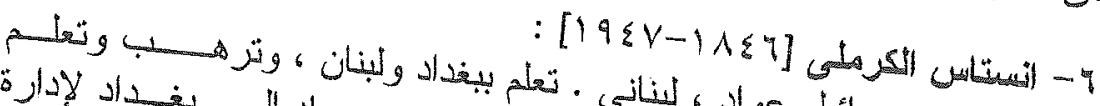

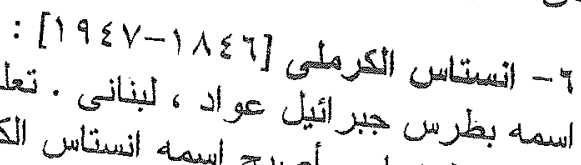

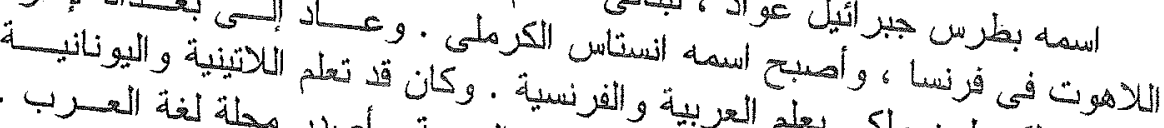

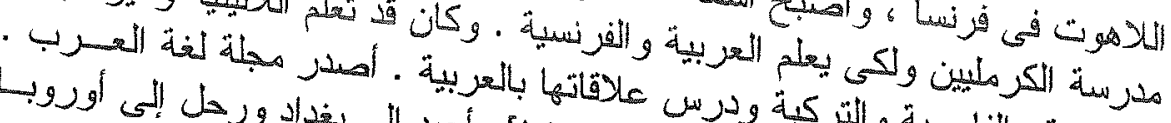

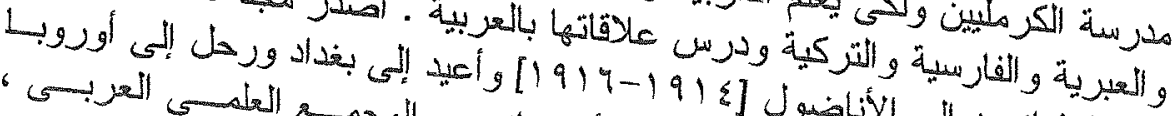

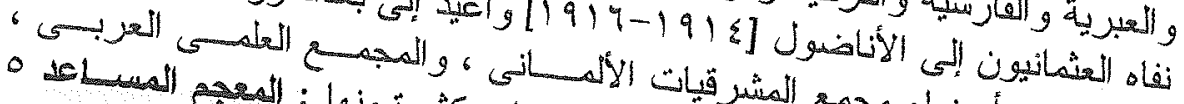

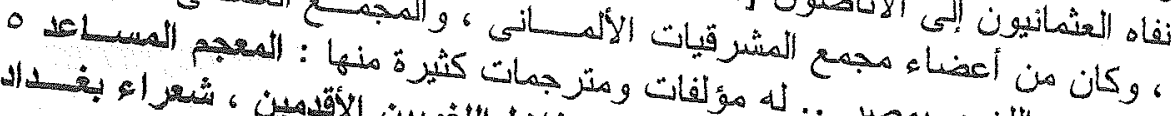

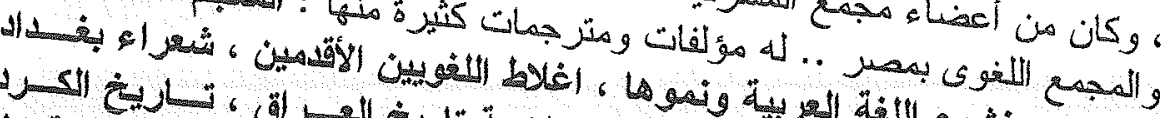

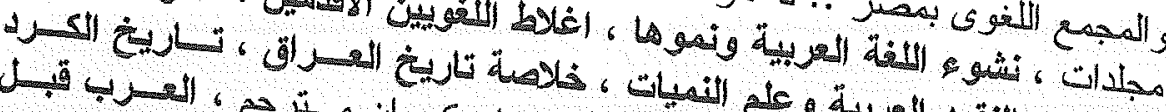

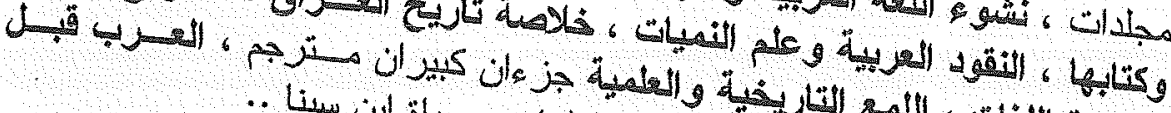

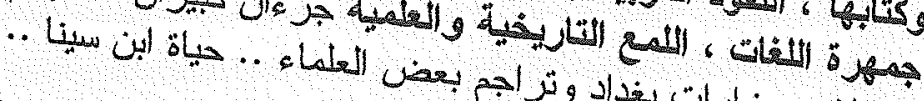

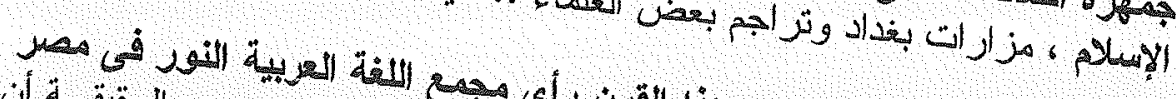

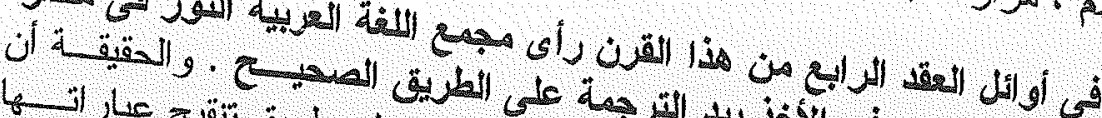

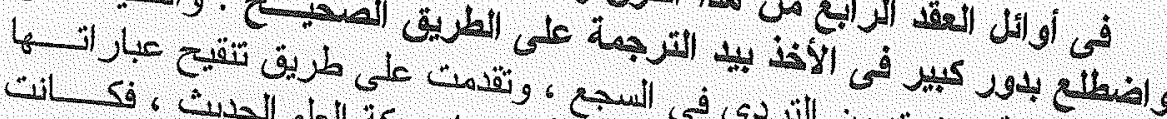

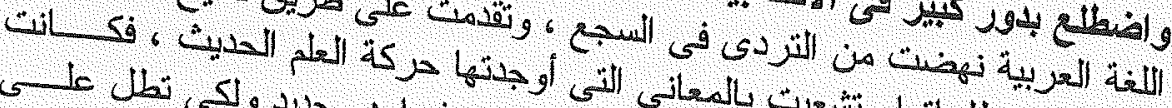

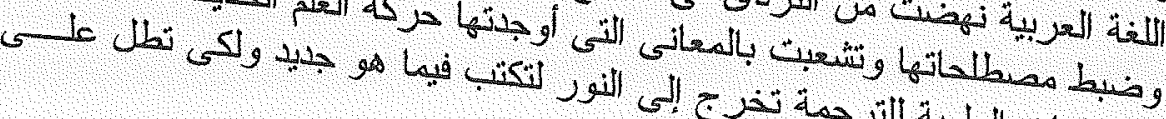

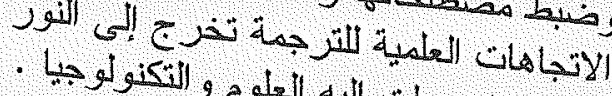




\section{أهم المراجية}

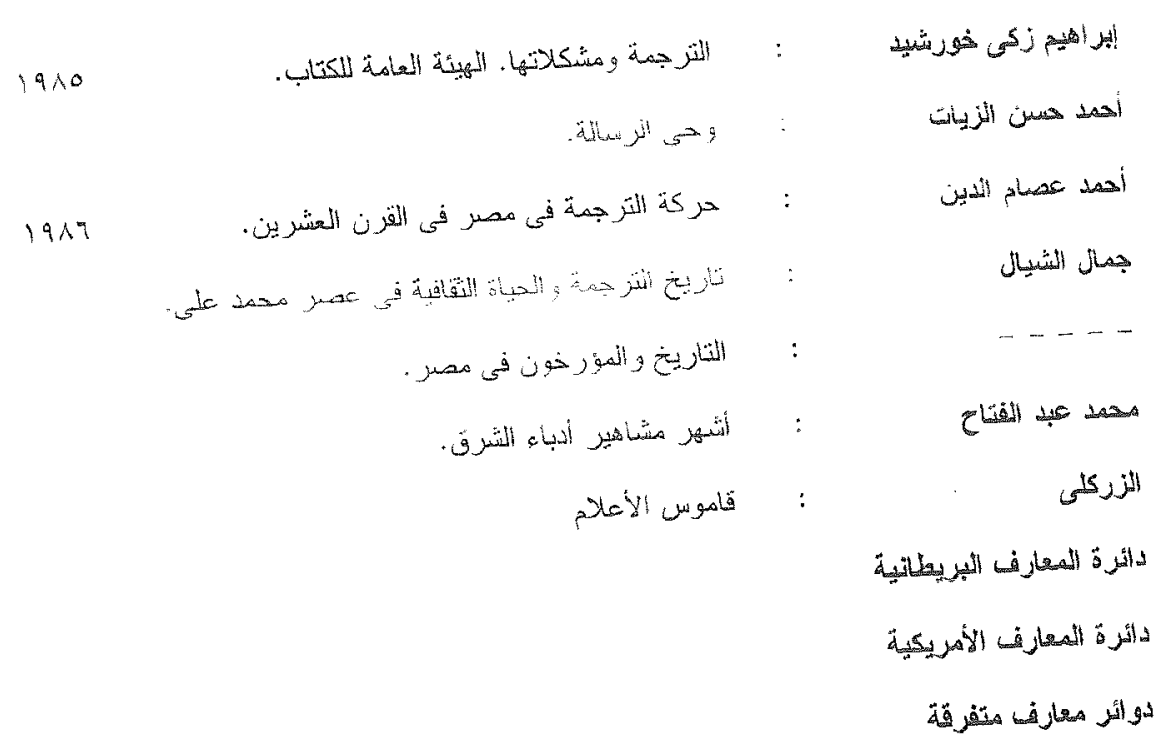

